\title{
Review of clinical aspects, epidemiology and diagnosis of haemotropic Mycoplasma ovis in small ruminants: current status and future perspectives in tropics focusing on Malaysia
}

\author{
Bura Thlama Paul ${ }^{1,2}$ (D) Faez Firdaus Abdullah Jesse ${ }^{1,3} \cdot$ Eric Lim Teik Chung ${ }^{3,4} \cdot$ Azlan Che-Amat $^{1}$. \\ Mohd Azmi Mohd Lila ${ }^{5} \cdot$ Hamza Abdirahman Hashi ${ }^{1} \cdot$ Mohd Jefri Norsidin $^{1}$
}

Received: 30 July 2019 / Accepted: 21 July 2020 / Published online: 26 July 2020

(C) Springer Nature B.V. 2020

\begin{abstract}
Mycoplasma ovis (formerly Eperythrozoon ovis) is an epierythrocytic parasitic bacterium of small ruminants known as haemotropic mycoplasma, which is transmitted mechanically by biting flies and contaminated instruments. Acute mycoplasmosis causes severe haemolytic anaemia and mortality in young animals. At the same time, chronic disease may produce mild anaemia and varying degrees of morbidity depending on several factors, including age, reproductive status, the plane of nutrition, immunological status and the presence of concurrent infection. Haemotropic Mycoplasma ovis is currently recognised as an emerging zoonotic pathogen which is widely distributed in the sheep and goat producing areas of tropics and subtropics, where the disease is nearly endemic. Human infection has been reported in pregnant women, immunocompromised patients and people exposed to animals and arthropods. The current diagnosis of haemoplasma relies on microscopic evaluation of Giemsa-stained blood smear and PCR. Although there are few published reports on the incidence of haemotropic Mycoplasma ovis infection of small ruminants in Malaysia, information on its prevalence, risk factors, severity and economic impacts is grossly inadequate. Therefore, a large-scale survey of small ruminant flocks is necessary to elucidate the current seroprevalence status and molecular characteristics of haemotropic M. ovis infection in Malaysia using ELISA and PCR sequencing technologies. In the future, surveillance programs, including vector forecast, quarantine, monitoring by periodic surveys and public enlightenment, will limit the internal and transboundary spread of $M$. ovis, enhance control efforts and mitigate production losses in Malaysia.
\end{abstract}

Keywords Diagnosis $\cdot$ Epidemiology $\cdot$ Haemotropic Mycoplasma ovis $\cdot$ Small ruminants

Electronic supplementary material The online version of this article (https://doi.org/10.1007/s11250-020-02357-9) contains supplementary material, which is available to authorized users.

Faez Firdaus Abdullah Jesse jesse@upm.edu.my

1 Department of Veterinary Clinical Studies, Faculty of Veterinary Medicine, Universiti Putra Malaysia (UPM), 43400 Serdang, Selangor, Malaysia

2 Veterinary Teaching Hospital, Faculty of Veterinary Medicine, University of Maiduguri, 600230 Maiduguri, Borno, Nigeria

3 Institute of Tropical Agriculture and Food Security, Universiti Putra Malaysia (UPM), Serdang, Selangor, Malaysia

4 Department of Animal Science, Faculty of Agriculture, Universiti Putra Malaysia, 43400 Serdang, Selangor, Malaysia

5 Department of Veterinary Pathology and Microbiology, Faculty of Veterinary Medicine, Universiti Putra Malaysia, 43400 Serdang, Selangor, Malaysia

\section{Introduction}

Mycoplasma ovis (previously known as Eperythrozoon ovis) was first reported by Neitz et al. (1934) who described the appearance of ring, ovoid, round, dumbbell and commashaped bodies $(0.5-1 \mu \mathrm{m})$ attached to the surface of erythrocytes or lying extracellularly in sheep blood. Neimark et al. (2004) using electron microscope later described M. ovis as round or oval bodies $(0.3-0.4 \mu \mathrm{m})$ surround by $20-30 \mathrm{~nm}$ electron-dense layer on the surface of the red blood cell membrane. Eperythrozoon ovis was formally classified as Rickettsia in the family Anaplasmataceae along with Haemobartonella and Anaplasma (Table 1) based on their biological and morphological characteristics (Neimark et al. 2001).

Recent molecular analysis of the 16S rRNA gene sequence of E. ovis revealed striking similarities to the Mycoplasma 
Table 1 Morphological relationships with the principal genera of Anaplasmataceae (Neitz et al. 1934)

\begin{tabular}{lllll}
\hline S/N & Genus & Morphology & Position & Organisms/cell \\
\hline 1. & Anaplasma & Round, oval, irregular & Intracellular & 1-2, rarely 3-4 \\
2. & Haemobartonella & $\begin{array}{c}\text { Highly pleomorphic cocci, ovoid, rod, ring, } \\
\text { dumbbell, comma and irregular forms 0.6 } \mu \mathrm{m}\end{array}$ & $\begin{array}{c}\text { Intracellular } \\
\text { Large numbers within one cell }\end{array}$ \\
3. & $\begin{array}{c}\text { Eperythrozoon (now } \\
\text { Mycoplasma) }\end{array}$ & $\begin{array}{c}\text { less pleomorphic rings and rods predominate } \\
0.5-1 \mu \mathrm{m}\end{array}$ & $\begin{array}{c}\text { Epicellular/ free } \\
\text { in the blood }\end{array}$ & $\begin{array}{c}\text { Occur in large numbers or cluster (3-8 per cell) } \\
\text { and affecting up to 100\% of cells }\end{array}$ \\
4. & Grahamella & Regular rods & Intracellular & Occur in large numbers (8-20) within one cell \\
\hline
\end{tabular}

genus (class Mollicutes). Consequently, Neimark et al. (2001) proposed the transfer of Eperythrozoon as a subgroup (haemotropic mycoplasma or haemoplasma) in the genus Mycoplasma to reflect their phylogenetic affiliation. As a result, Eperythrozoon ovis was renamed Mycoplasma ovis comb. nov., which has a single circular chromosome (approximately $702,511 \mathrm{bp}$ ) containing two copies of the 16S rRNA gene corresponding to $M$. ovis and "Candidatus Mycoplasma haemovis" (Deshuillers et al. 2014). Both genotypes of Mycoplasma ovis are morphologically indistinguishable (Tagawa et al. 2012a) haemotropic bacteria of sheep and goats (Neimark et al. 2004; Hornok et al. 2009; Wang et al. 2017) which also infect deer, reindeer (Grazziotin et al., 2011a; Grazziotin et al., 2011b; Stoffregen et al., 2013) and humans (Sykes et al., 2010).

Generally, haemoplasma infection in small ruminants is associated with anaemia and various degrees of morbidity (Hornok et al. 2011). M. ovis infection in ewes is also associated with decreased production outcomes in terms of milk, weight gain, abortion, and increased lamb mortality (Urie et al., 2019). Similarly, poor reproductive performance and lowered milk yield have been associated with haemoplasma infection in dairy cows (Smith et al. 1990; Messick 2004). Recent molecular studies also detected "Ca. M. haemobos" and $M$. wenyonii in calves and aborted foetuses of infected cows (Hornok et al. 2011; Girotto-Soares et al. 2016). Based on cumulative evidence obtained from previous studies, the involvement of reproductive tissues is an aspect of haemoplasma infection requiring further investigations to elucidate the physiological and molecular mechanisms. So far, infections of $M$. ovis occurred in Malaysia (Fatimah et al. 1998; Jesse et al. 2013, 2015, 2017), Japan (Tagawa et al. 2012a), China (Wang et al. 2017; Shi et al. 2018) and most recently in the Philippines (Galon et al., 2019). However, the unavailability of quantitative data on production losses presents difficulty in assessing the economic impact of $M$. ovis on the small ruminant industry in the far eastern territories. Despite the prevalence, potential economic and zoonotic implications of haemotropic $M$. ovis in the region, there is a dearth of published information on its epidemiology in Malaysia. Therefore, the objective of this review is to present current research information on the clinical aspects, epidemiology, diagnosis and directions for future research on haemotropic mycoplasmosis among small ruminants in the tropics focusing on Malaysia.

\section{Clinicopathological aspects of Mycoplasma ovis infection in small ruminants}

\section{Pathogenesis and pathology of Mycoplasma ovis}

After mechanical or iatrogenic transmission, the bone marrow is the primary site of Mycoplasma ovis multiplication before the appearance of parasitaemia after a variable incubation period (Kanabathy and Nachiar 2004). Neitz et al. (1934) observed parasitaemia within 5-7 days in most experimentally infected sheep, while Littlejohns (1960) reported an incubation period of 12 days post-infection (pi) in sheep. Additionally, Norris et al. (1987) observed peak levels of parasitaemia and anaemia at 8-15 and 20-30 days pi in experimentally infected sheep. It appears that the incubation period of $M$. ovis in experimentally infected sheep is inversely proportional to the size of the infecting dose (Sutton and Jolly 1973). Foogie and Nisbet (1964) observed shorter incubation periods in sheep experimentally infected with heavily parasitised blood, while Mason and Statham (1991) observed more extended incubation periods after inoculating low doses of $M$. ovis in sheep. The parasitaemia which develops in the course of natural or experimental $M$. ovis infection in small ruminant can be described as mild (1 to $29 \%$ infected cells), moderate (30 to $59 \%$ infected cells) or severe (60\% or more infected cells) depending on the percentage of parasitised erythrocytes (Gulland et al. 1987a; Hampel et al., 2014).

The clinical course of haemoplasma infection may vary considerably depending on the species of parasite, the host animal and the presence of concurrent infection (Reagan et al. 1990). Uncomplicated Mycoplasma ovis infection in sheep is typically asymptomatic because of its low pathogenic potential (Porter and Kaplan 2011). Therefore, chronic infections with mild parasitaemia and regenerative anaemia are the characteristic features of disease under field conditions (Gulland et al. 1987b). However, severe haemolytic anaemia and concurrent infections may occur during acute field 
outbreaks (Jesse et al. 2015) and immunocompromised states (Boes and Durham, 2016). Also, acute infection of small ruminants causes severe haemolytic anaemia, weakness, decreased exercise tolerance and concurrent chronic infections (Fitzpatrick et al. 1998). Abed and Alsaad (2017) observed anaemia and anorexia in more than $80 \%$, respiratory distress and lymphadenopathy in less than $80 \%$, haemoglobinuria in $42 \%$ and decreased milk production in $39 \%$ of acutely infected sheep under field conditions. Generally, mild anaemia, ill thrift, reduced weight gain, jaundice, exercise intolerance, decreased wool and milk production are the main features of chronic $M$. ovis infection in sheep and goats (Fitzpatrick et al. 1998; Hornok et al. 2009; Machado et al. 2017).

The severity of anaemia in acute disease varies among susceptible individuals in a flock depending on their age, reproductive status, immunological status, nutritional state and the presence of concurrent infections (Hornok et al. 2009; Jesse et al. 2015). Although the infection may occur in all age groups of small ruminants, profound haemolytic anaemia, icterus, haemoglobinuria, reduced weight gain and mortality are frequently encountered in weaner sheep (Campbell et al. 1971; John and Invermay 1990; Neimark et al. 2004; Robson and Kemp 2007). On the other hand, infection is usually present as mild bacteraemia and less severe anaemia in older sheep and goats (Gulland et al. 1987a) due to the presence of acquired immunity (Hornok et al. 2009). However, adult sheep may occasionally succumb to acute infection and develop haemolytic anaemia due to stress form pregnancy, parturition, handling, malnutrition and concurrent parasitic, viral or bacterial infections and other immunosuppressive conditions (Gulland et al. 1987b; Fitzpatrick et al. 1998; Hornok et al. 2009; Sykes et al., 2010).

Associated changes in the blood due to deformation of erythrocyte membrane (Gulland et al. 1987a), increased membrane fragility (Norris et al. 1987) and erythrophagocytosis (Philbey et al. 2006) result in anaemia characterised by a significant decrease in the numbers of circulating erythrocytes, haematocrit and haemoglobin and the deposition of haemosiderin in tissues (Abed and Alsaad 2017). Although the pathogenic mechanisms of anaemia in Mycoplasma ovis infection are not entirely understood, there are strong indications that host immune reactions play an essential role in the development of acute and chronic infections (Messick 2004). Humoral immunity in sheep leads to the production of antierythrocyte antibody, agglutination of red blood cells and phagocytosis by Kupffer cells in the liver and reticular cells in lymphoid tissues (Kanabathy and Nachiar 2004). Additionally, direct injury to the red blood cell and innocent bystander effect due to the presence of $M$. ovis cells on erythrocytes are also involved in the development of haemolytic anaemia (Boes and Durham, 2016). Furthermore, oxidative injury, disruption of cell functions, immune evasion and secretion of lytic enzymes by haemoplasmas contribute to the development of haemolytic anaemia (Theiss et al. 1996). A poor condition characterised by stunted growth, delayed attainment of sexual maturity, decreased exercise tolerance, potbelly, emaciation and pallor are consistent features of the disease in lambs (Kanabathy and Nachiar 2004).

The pathological features of Mycoplasma ovis infection in sheep vary considerably depending on the degree of infection severity. At post-mortem, the carcase appears pale and wet with a gelatinous epicardial fat on the heart and moderate non-suppurative pneumonia in the lungs (Fitzpatrick et al. 1998). The spleen is markedly enlarged (splenomegaly), congested and soft with a prominent white pulp. The kidneys are also enlarged and have a distinctive rust-brown discolouration due to deposition of haemosiderin (Kanabathy and Nachiar, 2004). Additionally, the gallbladder is distended with bile (cholecystitis), and evidence of vasculitides such as oedema and exudates are present in body tissues or cavities. The common histological lesions associated with $M$. ovis infection include enlargement of the Malpighian corpuscles, haemosiderosis of the spleen and kidneys, moderate periacinar necrosis in the liver, depletion of lymphoid tissues in the spleen and lymph nodes and lymphoid hyperplasia in the haemal nodes (John and Invermay 1990; Philbey et al. 2006).

\section{Co-infections of Mycoplasma ovis}

Co-infection of red blood cells with multiple species of vectorborne haemoprotozoa or bacteria is a common finding in farm animals (Ait Lbacha et al., 2015). Co-infection of Ehrlichia ewingii and haemotropic Mycoplasma in a goat resulted in macrocytic hypochromic anaemia with anisocytosis, macrocytosis and basophilic stippling as well as increased AST, CK, GGT and decreased ALP activities (Meichner et al., 2015). Likewise, co-infections of erythrocytes with haemotropic Mycoplasma and Anaplasma species in sheep and goats were also reported in Morocco (Ait Lbacha et al., 2015). Similarly, Aktas and Ozubek (2017) reported a significant association between haemotropic Mycoplasma ovis infection and the presence of Babesia and Theileria infection among sheep flocks in Turkey. Furthermore, co-infections of sheep with haemotropic Mycoplasma ovis and Anaplasma/Babesia species are associated with increased severity of anaemia in chronic disease (Neimark and Kocan 1997). Also, persistent co-infection of haemotropic Mycoplasma ovis and Bartonella henselae has been reported in a Veterinarian with a history of protracted illness and nonspecific signs (Sykes et al., 2010). Concurrent infection with tick-borne haemopathogens such as Theileria, Babesia, Anaplasma and Ehrlichia increase the susceptibility of animals to haemotropic mycoplasmosis (Varanat et al., 2011) because the presence of multiple co-infecting pathogens provokes a complex divergent or similar responses that allow synergy and more successful colonisation in the host (Baneth, 
2014). Interestingly, all the vector-borne haemopathogens involved in co-infections of haemotropic mycoplasmosis cause haemolytic anaemia (Jabbar et al., 2015). Similarly, concurrent parasitic gastroenteritis due to Haemonchus contortus and other pathogenic Strongyles increased the severity of anaemia and pathology of haemotropic mycoplasmosis in sheep and goats (Jesse et al. 2013, 2015, 2017). Both parasitic gastroenteritis (PGE) and haemotropic mycoplasmosis are associated with anaemia, bottle jaw and weight loss in small ruminants, and there is a consensus that haemoplasmas can act synergistically with highly pathogenic nematodes such as Haemonchus contortus and contribute to the severity of disease in a concurrently infected flock (Souza et al., 2019). Although the exact mechanism by which co-infecting parasites contributes to the severity of haemotropic mycoplasmosis is not fully understood, other immunosuppressive conditions such as pregnancy, lactation, parturition and malnutrition also increase the severity of disease in small ruminants (Philbey et al. 2006). Moreover, the clinical signs of experimental haemoplasma infection are enhanced by splenectomy or daily administration of dexamethasone in animal models (Neitz et al. 1934; Yuan et al. 2007b). It is, therefore, logical to conclude that the immunosuppressive effects of concurrent infections enhance the severity of haemotropic mycoplasmosis in small ruminants (Sykes et al., 2010).

\section{Immune response of small ruminants to Mycoplasma ovis infection}

The pioneer experimental works of Neitz et al. (1934) revealed that previously infected small ruminants were resistant to subsequent challenge by Mycoplasma ovis. In 1967, Ohder and co-workers demonstrated the presence of circulating antibodies which conferred resistance and inhibited reinfection in sheep. Hung and Lloyd (1985) further demonstrated that specific antibody response results from M. ovis infection in sheep. Nicholls and Veale (1986) detected specific antibody which suppressed parasitaemia and prolonged the prepatent period of infection in passively immunised sheep. The resultant degree of immunity depended on the persistence of infection and duration of parasitaemia and anaemia in experimentally infected sheep (Gulland et al. 1987b). The onset of humoral immunity to $M$. ovis is within 1 to 2 weeks postinfection, and the spleen is actively involved in the development and maintenance of resistance in sheep because splenectomised animals become susceptible to infection (Kanabathy and Nachiar 2004; Cebra and Cebra 2012). It is also known that pitting process by pseudopodia in macrophage, and reticular cells of the spleen are responsible for the clearance of parasitaemia by physical detachment from the erythrocyte membrane in the spleen (Hung and Lloyd 1989).

\section{Epidemiology of Mycoplasma ovis in small ruminants}

\section{Life cycle and transmission of Mycoplasma ovis}

Haemotropic mycoplasmas are obligate epicellular bacteria known to be mechanically transmitted by various species of haematophagous arthropods such as Stomoxys calcitrans, Haematobia irritans, Tabanus bovinus, T. bromius, Melophagus ovinus, midges and mosquitoes (Hornok et al. 2009, 2011; Sykes et al. 2010). Recent molecular studies also provide evidence of mechanical transmission by various tick species such as Amblyomma, Hyalomma, R. (Boophilus), Rhipicephalus and Haemaphysalis (Aktas and Ozubek 2017; Mohd Hassan et al. 2017; Machado et al. 2017; Shi et al. 2018) and lice (Neimark et al. 2001). The preponderance of arthropod vectors is therefore considered an essential factor in the epidemiology of haemoplasmas. In the past, seasonal changes in arthropod density and distribution influenced the prevalence of Mycoplasma ovis infection among sheep in Australia (Daddow, 1980). Likewise, the presence of ticks on small ruminants is associated with haemoplasma-positive status and disease severity (Aktas and Ozubek 2017). High biting activity is also known to be essential for natural vectorborne transmission under field conditions where low levels of parasitaemia subsist because the minimum infective dose of M. ovis is one parasitised erythrocyte (Mason and Statham 1991). However, it is not clear if the mechanism of natural arthropod-borne transmission is merely mechanical or involves a cyclical transovarial process. It is also possible that heavy blood-feeding by arthropods, apart from contributing to the mechanical transmission of $M$. ovis and other vector-borne pathogens, may cause significant blood losses and increase the severity of anaemia. Tropical temperatures, rainfall and humidity are favourable for the propagation of haematophagous arthropods and account for the high prevalence of vectorborne diseases in tropics and subtropics (Jongejan and Uilenberg 1994). Tick vectors such as Boophilus, Dermacentor, Ixodes, Haemaphysalis and Rhipicephalus species (Khadijah et al. 2014); biting flies such as Tabanus, Stomoxys and Haematobia (Chin et al. 2010; Erwanas et al. 2015); and mosquitoes such as Aedes albopictus, Aedes aegypti, and Culex quinquefasciatus (Saleeza et al. 2013) are prevalent in Malaysia. However, their role in the transmission of Mycoplasma ovis in small ruminant flocks is unknown in Malaysia. There is also molecular evidence supporting the possibility of transplacental transmission of haemoplasma infection in cattle (Hornok et al. 2011). Nevertheless, it is not clear whether $\mathrm{M}$. ovis and " $\mathrm{Ca}$. M. haemovis" infect reproductive tissues and undergo transplacental transmission during pregnancy in small ruminants. Iatrogenic transmission through contaminated needles, ear tag applicators and wool shearing or mulesing equipment also plays a significant role in 
the epidemiology of $M$. ovis in small ruminant flocks (Campbell et al. 1971).

\section{Global distribution, prevalence and zoonotic potential of Mycoplasma ovis}

M. ovis and the related haemoplasmas represent a phylogenetic cluster of cell-wall deficient uncultivated epierythrocytic parasitic bacteria which are currently recognised as emerging or re-emerging zoonotic pathogens causing substantial economic losses and public health problems worldwide (Hornok et al. 2009; Huang et al. 2012; Jesse et al. 2015; Machado et al. 2017; Wang et al. 2017). Haemotropic mycoplasmas have been reported in a wide range of domestic mammals (cattle, buffalo, sheep, goats, deer, pigs, dogs, cats), wild mammals (bear, racoon, opossums), camelids (alpaca), primates (monkey), rodents (rats, mice) bats and man (Table 2). Wild animals have been recognised as reservoirs hosts that play a central role in the epidemiology of various species of vector-borne infections (Baneth, 2014).

Mycoplasma ovis occurs in the sheep and goat producing areas in the tropics and subtropics (Neimark et al. 2004). The prevalence of Mycoplasma ovis and the nature of the diagnostic tests vary considerably in different parts of the world (Table 3). Historically, Ilemobade and Blotkamp (1978b) detected $36 \%$ seropositivity among sheep in Nigeria using indirect immunofluorescent antibody test (IFAT). Mason et al. (1989) later detected 49\% seroprevalence among sheep in Australia using IFAT. While using ELISA for the first time in a field survey, Kabay and co-workers (Kabay et al. 1991) detected $4.5 \%$ seroprevalence of $M$. ovis among sheep in Australia. To date, however, the highest seroprevalence of Mycoplasma ovis is from Iraq, where $100 \%$ of sheep tested positive to indirect ELISA (Abed and Alsaad 2017). The molecular prevalence of Mycoplasma ovis based on PCR and sequencing reveals between 6.3 and $100 \%$ infection rates in small ruminants worldwide. PCR results revealed a

Table 2 Reported species and host tropisms of haemotropic mycoplasmas

\begin{tabular}{|c|c|c|c|}
\hline $\mathrm{S} / \mathrm{N}$ & Species & Host range & References \\
\hline 1. & Mycoplasma ovis & Goats, sheep, deer, reindeer, human & $\begin{array}{l}\text { Neimark et al. (2004); Stoffregen et al. (2006); Hornok et al. } \\
\text { (2009) }\end{array}$ \\
\hline 2. & Candidatus M. haemovis & Goats, sheep & Suzuki et al. (2011); Hornok et al. (2012); Wang et al. (2017) \\
\hline 3. & M. wenyonii & Cattle, buffalo, sheep & $\begin{array}{l}\text { Smith et al. (1990); Neimark and Kocan (1997); Scott (2008); } \\
\text { Mohd Hassan et al. (2017); Aktas and Ozubek (2017) }\end{array}$ \\
\hline 4. & M. haemobos & Cattle, buffalo, sheep, goats & $\begin{array}{l}\text { Su et al. (2010); Hoelzle et al. (2011); Hornok et al. (2011); Mohd } \\
\text { Hassan et al. (2017); Shi et al. (2018) }\end{array}$ \\
\hline 5. & M. haemosuis & Pigs, human & $\begin{array}{l}\text { Messick et al. (1999); Neimark et al. (2002); Yuan et al. (2009); } \\
\text { Song et al. (2014a) }\end{array}$ \\
\hline 6. & M. haemofelis & Cat, human, racoon & $\begin{array}{l}\text { Neimark et al. (2002); Lobetti and Tasker (2004); Vergara et al. } \\
\text { (2016); Volokhov et al. (2017) }\end{array}$ \\
\hline 7. & Candidatus $\mathrm{M}$. haemominutum & Cat & $\begin{array}{l}\text { Foley and Pedersen (2001); Lobetti and Tasker (2004); Vergara } \\
\text { et al. (2016) }\end{array}$ \\
\hline 8. & Candidatus $\mathrm{M}$. turicensis & Cat & Lobetti and Tasker (2004); Vergara et al. (2016) \\
\hline 9. & M. haemocanis & Dog, bear, racoon & $\begin{array}{l}\text { Neimark et al. (2002); Biondo et al. (2009); Kaewmongkol et al. } \\
\text { (2017); Volokhov et al. (2017); Westmoreland et al. (2017) }\end{array}$ \\
\hline 10. & Candidatus M. haemoparvum & Dog, human, bear & $\begin{array}{l}\text { Kaewmongkol et al. (2017); Westmoreland et al. (2017); Aktas } \\
\text { and Ozubek (2018) }\end{array}$ \\
\hline 11. & Candidatus M. haemolamae & Alpaca, deer, reindeer, racoon & $\begin{array}{l}\text { Messick et al. (2002); Stoffregen et al. (2006); Grazziotin et al. } \\
\text { (2011a); Boes et al. (2012) }\end{array}$ \\
\hline 12. & M. haemomacaque & Monkey & Maggi et al. (2013) \\
\hline 13. & M. erythrocervae & Deer, reindeer & Grazziotin et al. (2011b); Tagawa et al. (2014) \\
\hline 14. & Ca. M. haemocervae & Sika deer & Tagawa et al. (2014) \\
\hline 15. & $\begin{array}{l}\text { Candidatus } \mathrm{M} \text {. } \\
\text { haemotarandirangiferis }\end{array}$ & $\begin{array}{l}\text { Dwarf brocket deer, red brocket deer, } \\
\text { marsh deer, white-tailed deer }\end{array}$ & Grazziotin et al. (2011b) \\
\hline 16 & Candidatus M. haemodidelphidis & Opossums & Messick et al. (2002) \\
\hline 17 & Mycoplasma haemomuris & Rats, mice & Rikihisa et al. (1997); Mascarelli et al. (2014) \\
\hline 18 & Candidatus M. haemohominis & Human, bats & Steer et al. (2011); Mascarelli et al. (2014); Millán et al. (2015) \\
\hline 19 & Candidatus M. kahanei & Monkeys & Cubilla et al. (2017) \\
\hline
\end{tabular}


Table 3 Prevalence, host range and diagnosis of Mycoplasma ovis infection in different parts of the world

\begin{tabular}{|c|c|c|c|c|}
\hline Country & Study population & Prevalence & Diagnostic technique & Reference \\
\hline Australia & Sheep & Case report & Blood smear examination & Campbell et al. (1971) \\
\hline Australia & Sheep, goats & $44.9 \%$ & FAT & Mason et al. (1989) \\
\hline Australia & Sheep & $4.5 \%$ & ELISA & Kabay et al. (1991) \\
\hline Brazil & Captive deer & $87 \%$ & Conventional PCR (16S and 23S rRNA genes) & Grazziotin et al. (2011b) \\
\hline Brazil & Free-ranging deer & $58 \%$ & Conventional PCR (16S rRNA gene) & Grazziotin et al. (2011a) \\
\hline Brazil & Goats & $39.3 \%$ & Conventional PCR (16S rRNA gene) & Machado et al. (2017) \\
\hline Brazil & Sheep & $78.8 \%$ & Conventional PCR (16S rRNA gene) & Souza et al. (2019) \\
\hline China & Human & Case report & Blood smear examination, PCR (16S rRNA gene) & Yuan et al. $(2007 a, b)$ \\
\hline China & Goats & $41 \%$ & Semi-nested PCR (16S rRNA gene) & Song et al. $(2014 \mathrm{a}, \mathrm{b})$ \\
\hline China & Sheep and goats & $44.7 \%$ & Nested PCR, (16S rRNA gene) & Wang et al. (2017) \\
\hline Hungary & Sheep & $51.5 \%$ & TaqMan PCR, conventional PCR (16S rRNA gene) & Hornok et al. (2009) \\
\hline Hungary & Goats & $20 \%$ & Real-time PCR (16S rRNA gene) & Hornok et al. (2012) \\
\hline Iraq & Sheep & $100 \%$ & Blood smear, ELISA & Abed and Alsaad (2017) \\
\hline Iraq & Sheep & $17.5 \%$ & Conventional PCR (16S rRNA gene) & Kshash (2017) \\
\hline Japan & Sheep & Case report & Blood smear examination, PCR (16S rRNA gene) & Suzuki et al. (2011) \\
\hline Japan & Sheep & $50 \%$ & Blood smear, PCR (16S rRNA gene) & Tagawa et al. (2012a, b) \\
\hline Malaysia & Goat & Case report & Blood smear examination & Jesse et al. (2013) \\
\hline Malaysia & Goats & $94 \%$ & Blood smear examination & Jesse et al. (2015) \\
\hline Malaysia & Sheep & Case report & Blood smear examination & Jesse et al. (2017) \\
\hline Mexico & Sheep & $100 \%$ & Blood smear examination, PCR (16S rRNA gene) & Martínez-Hernández et al. (2019) \\
\hline New Zealand & Sheep & Case report & Blood smear examination & John and Invermay (1990) \\
\hline Nigeria & Sheep & $36 \%$ & IFAT, blood smear examination & Ilemobade and Blotkamp (1978b) \\
\hline North America & Goats & $18.0 \%$ & Real-time PCR (16S rRNA gene) & Johnson et al. (2016) \\
\hline Philippines & Goats & $36.3 \%$ & Conventional PCR (16S rRNA gene) & Galon et al. (2019). \\
\hline Scotland & Sheep & Case report & Blood smear examination & Fitzpatrick et al. (1998) \\
\hline Turkey & Sheep & $9 \%$ & Conventional PCR (16S rRNA gene) & Aktas and Ozubek (2017) \\
\hline Tunisia & Sheep and goats & $6.3 \%$ & Conventional PCR (16S rRNA gene) & Rjeibi et al. (2015) \\
\hline USA & Human & Case report & Conventional PCR (16S rRNA gene) & Sykes et al. (2010) \\
\hline USA & Deer & Case report & Conventional PCR (16S and 18S rDNA genes) & Boes et al. (2012) \\
\hline USA & Human & $4.7 \%$ & Conventional PCR (16S rRNA gene) & Mascarelli et al. (2013) \\
\hline USA & Sheep & $14.1 \%$ & Blood smear examination, PCR (16S rRNA gene) & Hampel et al. (2014) \\
\hline USA & Sheep & $73.3 \%$ & Conventional PCR (16S rRNA gene) & Urie et al. (2019) \\
\hline
\end{tabular}

prevalence of $6.3 \%$ in Tunisia (Rjeibi et al. 2015), 9\% in Turkey (Aktas and Ozubek 2017), 14.1\% in the USA (Hampel et al. 2014), 17.5\% in Iraq (Kshash 2017), 18\% in North America (Johnson et al. 2016), 39.3\% in Brazil (Machado et al. 2017), 44.7\% in China (Wang et al. 2017), $50 \%$ in Japan (Tagawa et al. 2012a), 51.5\% in Hungary (Hornok et al. 2009) and 100\% in Mexico (MartínezHernández et al., 2019). In the past, outbreaks of disease also occurred in Australia (Campbell et al. 1971), Germany (Neimark et al. 2004), Hungary (Hornok et al. 2009), Argentina (Aguirre et al. 2009), Japan (Tagawa et al. 2012a), Malaysia (Jesse et al. 2013, 2015, 2017), Tunisia (Rjeibi et al. 2015), Turkey (Aktas and Ozubek 2017),
China (Wang et al. 2017) and most recently in Mexico (Martínez-Hernández et al. 2019). On the other hand, only sporadic clinical cases have been reported in Scotland (Fitzpatrick et al. 1998), the USA (Boes et al. 2012; Sykes et al. 2010) and North America (Johnson et al. 2016).

Records of human haemotropic mycoplasma infection are poorly documented in the past due to underdiagnosis and the absence of justification for epidemiological significance (Biondo et al. 2009). Nonetheless, Yang and co-workers (Yang et al. 2000) reported $35.3 \%$ prevalence of human haemotropic mycoplasma infection with $57 \%$ and $100 \%$ infection rates in women and their new-born babies in inner Mongolia. Furthermore, recent molecular studies reported 
M. ovis-like, M. haemofelis-like, M. haemominutum, $M$. haematoparvum and $\mathrm{Ca}$. M. haemohominis infection in humans (Chu et al. 2009; Sykes et al. 2010; Steer et al. 2011; Mascarelli et al. 2013). As more human infections are diagnosed, haemotropic mycoplasmosis is currently emerging as a zoonotic concern and occupational hazard, especially in veterinarians, veterinary workers, veterinary students, herdsmen, wildlife workers and pastoral communities which have frequent exposure to animals and the arthropod vectors of haemoplasma (Yang et al. 2000; Huang et al. 2012; Mascarelli et al. 2013). Moreover, the risk of human haemotropic mycoplasmosis is also being recognised among HIV patients due to their poor immunological status (dos Santos et al. 2008; Sykes et al. 2010; Mascarelli et al. 2013).

\section{Haemotropic mycoplasmosis in East Asia}

Few countries in East Asia have documented specific reports on haemotropic mycoplasmosis in small ruminants. The pioneer studies conducted in China have documented $16.1 \%$ prevalence of $M$. ovis among goats in Chongqing (Zuo-yong et al. 2010) and $41.0 \%$ prevalence among sheep and goats in Hubei Province (Song et al. 2014b). Besides, recent molecular studies have reported $44.7 \%$ prevalence of $\mathrm{M}$. ovis and $\mathrm{Ca}$. M. haemovis in goats (Wang et al. 2017) and 53\% prevalence of "Ca. M. haemobos" in Boophilus microplus ticks collected from sheep and goat in China (Shi et al. 2018). Moreover, there are also reports on other haemoplasmas such as Candidatus Mycoplasma haemobos in bovine species (Song et al. 2010) and zoonotic M. suis in pig and humans (Yang et al., 2000; Yuan et al., 2009). The first report on haemotropic Mycoplasma ovis in Japan was in free-living Japanese serows (Ohtake et al. 2011). Later, Tagawa et al. (2012a) reported an outbreak involving haemotropic Mycoplasma ovis and "Candidatus Mycoplasma haemovis", where 50\% of sheep imported from Australia experienced severe anaemia (PCV 14\%). Also, there are reports on other related haemoplasma species such as $M$. wenyonii and $C a$. M. haemobos detected in cattle (Tagawa et al. 2012b), the novel "Candidatus Mycoplasma erythrocervae" and "Candidatus Mycoplasma haemocervae" in the sika deer (Watanabe et al., 2010; Tagawa et al. 2014). To date, there is no report on Mycoplasma ovis in small ruminants in North and South Korea. However, there are few reports on other haemotropic mycoplasmas such as "Candidatus M. haematoparvum", Mycoplasma haemocanis in dogs (Suh et al., 2017), M. suis, M. parvum and the novel Candidatus M. haemosuis in pigs (Seo et al., 2019). So far, there is a single report that shows $36.3 \%$ prevalence of haemotropic Mycoplasma ovis, Candidatus Mycoplasma haemobos, Candidatus Mycoplasma haemominutum and three unidentified haemoplasma species among goats in the Philippines (Galon et al., 2019). Also, there are reports on other haemoplasmas, including Mycoplasma species and M. wenyonii among cattle in the Philippines (Ybañez et al. 2015, 2019).

Several studies have documented various aspects of haemoplasma infection of small ruminants in Malaysia. Clinical cases of haemotropic mycoplasmosis were well recognised in Malaysia sheep and goats since the early 1990s. The earliest report was documented by Fatimah et al. (1994) who reported the first clinical case of haemotropic mycoplasmosis in a sheep which concurrently suffered copper toxicity. The first report was deficient in lacking necessary clinical data to support the diagnosis of haemotropic mycoplasmosis in sheep. Nearly two decades after the first report, a more comprehensive report which provided clinical details supporting the diagnosis of haemotropic mycoplasmosis was published. Based on this report, a young buck was presented to the large animal clinic of the Universiti Putra Malaysia (UPM) Veterinary Hospital with a complaint of diarrhoea and weakness for 1 week. The clinical details include an extended capillary refill time, pale mucous membranes, nasal discharge, $5 \%$ dehydration and mild diarrhoea. Further laboratory examinations yielded normocytic normochromic anaemia (PCV 14\%), hyponatraemia, hypocalcaemia, presence of haemotropic Mycoplasma species in thin blood film and 13,900 Trichostrongylid egg per gram of faeces, indicating a diagnosis of co-infection with parasitic gastroenteritis (PGE) and haemotropic mycoplasmosis (Jesse et al., 2013). The second report was also deficient in failing to identify the haemotropic mycoplasms species explicitly involved. In the next year, a rare case of haemotropic mycoplasmosis involving unidentified species of haemoplasma in a captive Malaysian pangolin was published (Jamnah et al. 2014). The presence of Mycoplasma species in wild animals raised serious questions among veterinarians as to the potential role of wild mammals as a reservoir in the epidemiology of haemotropic mycoplasmosis. The recent and most comprehensive case of haemotropic mycoplasmosis in Malaysia involved an adult ewe presented to the large animal clinical of the UPM Veterinary Hospital with a complaint of diarrhoea. Clinical examinations revealed pale mucous membrane, extended capillary refill time, fever, tachycardia and tachypnoea. Laboratory examinations revealed normocytic hypochromic anaemia $(\mathrm{PCV}=14 \%)$, neutrophilic left shift, uraemia, low creatinine, hyperbilirubinemia, presence of Mycoplasma ovis in blood smear and severe strongyle infection (3000 epg), indicating co-infection of haemotropic mycoplasmosis and severe worm burden (Jesse et al., 2017).

In addition to clinical case reports, there are also reports on field and laboratory investigation on the prevalence, severity, host responses and diagnosis of haemotropic mycoplasmosis in Malaysia. For instance, Fatimah et al. (1998) conducted the first field survey that documented the prevalence of Mycoplasma ovis in different geographical locations and further described the trends in parasitaemia and infection 
severity in sheep flocks. Further studies conducted by Ershaduazzaman and Iskandar (2001) described the detailed morphology, biochemistry and cultural behaviour of M. ovis isolated from Malaysian sheep flocks using scanning electron microscopy, immunofluorescent antibody, immunoblot and in vitro culture techniques. While studying immune mechanisms to $M$. ovis in naturally infected sheep flocks in Malaysia, Kanabathy and Nachiar (2004) observed that early peripheral blood response was dominated by neutrophils, lymphocytes and thrombocytes and the late response involved monocytes. The most recent field survey of haemotropic Mycoplasma ovis sampled goats in selected small ruminant flocks in Selangor and detected $94.0 \%$ prevalence of mild (93.6\%) and moderate (6.4\%) infections. Results of this study further revealed that $M$. ovis parasitaemia was associated with the nematode worm burden in goats (Jesse et al., 2015). Apart from M. ovis, other haemoplasmas such as Mycoplasma wenyonii and Candidatus M. haemobos were detected in $69.0 \%$ of blood and $30 \%$ of tick samples obtained from cattle by conventional PCR of the 16S rRNA gene in Malaysia (Mohd Hassan et al., 2017).

Lack of epidemiological data on haemotropic mycoplasmosis in many countries in East Asia is not a justification for the complete absence of disease. Also, regardless of available data on the prevalence of haemotropic mycoplasmosis due to $M$. ovis and Ca. M. haemovis in some countries, it appears that their actual host and geographic range are poorly defined in the region. Moreover, Mycoplasma ovis was previously thought to be specific to sheep and goats, but current literature has revealed a broader host range including deer, reindeer, wild animals and humans. Furthermore, there is no specific information on the risk factors associated with the prevalence of haemotropic mycoplasmosis in the affected countries. It is, therefore, necessary to conduct comprehensive field surveys to elucidate prevalence, risk factors and severity of haemotropic Mycoplasma ovis in different host species in the region, especially in Malaysia where the small ruminant industry is currently evolving. Future studies using advanced molecular diagnostic techniques may likely reveal additional mammalian hosts and geographical distribution of M. ovis in the Far East.

\section{Diagnosis of Mycoplasma ovis}

\section{In vitro culture}

Since its first discovery, attempts to cultivate $M$. ovis on laboratory media under different conditions have failed (Neitz et al., 1934). Mycoplasma ovis being an obligate epicellular bacterium is unstable in vitro, unable to grow on cell-free media and is readily destroyed by drying or exposure to disinfectants (Baker et al., 1971). Therefore, M. ovis is dependent on the host's microenvironment and complex culture medium for growth (Rani et al., 2018). "Sheep kidney culture" and "mixed hamster kidney-bovine lymphatic tissue culture" media were both unsuccessful in cultivating M. ovis. However, Seamer (1959), successfully passaged Eperythrozoon coccoides 14 times by yolk sac inoculation and 16 times by intravenous injection of the chick embryo. Ershaduazzaman and Iskandar (2001), using embryonated chicken eggs, successfully passaged $M$. ovis through the yolk sac and maintained its attachment to the red blood cell in heparinised samples by incubation in Eagle's medium supplemented with inosine and bovine foetal serum under $5 \% \mathrm{CO}_{2}$. Additionally, infected blood stored for 5 weeks at $-20^{\circ} \mathrm{C}$ produced clinical infection in susceptible sheep. Despite all these attempts, to date, there is no suitable method for in vitro cultivation of haemotropic mycoplasmas in the laboratory.

Therefore, the clinical diagnosis of Mycoplasma ovis is presently relying on detailed history supported by clinical evidence, laboratory analyses and post-mortem examination (Jain et al., 2011). Microscopic evaluation of stained blood smear, haematobiochemical analyses, serologic detection of antibodies and polymerase chain reaction detection of DNA are used so far in the diagnosis of Mycoplasma ovis infection in small ruminants (Neimark et al., 2004; Abed and Alsaad 2017). Despite the current advances in genotyping and molecular proteomics of various parasitic pathogens and the global emergence of haemotropic mycoplasmosis as an economic concern to small ruminant producers, there is still no comprehensive report on the genomic characteristics of haemotropic Mycoplasma ovis.

\section{Microscopic evaluation of blood smear}

Microscopic examination of blood smears stained with Romanowsky dyes was the earliest method used for the detection of haemoplasmas (Gulland et al., 1987a) and is still the first line in current laboratory diagnosis of $M$. ovis because it is fast cheap and easy to perform (Abed and Alsaad 2017). Under the light microscope, haemoplasmas may be bound to the surface of mammalian erythrocytes or found lying loosely in the plasma due to detachment from the cells, especially after prolonged storage of blood samples (Biondo et al., 2009). When detected on routine blood smear evaluation, M. ovis is present as basophilic pleomorphic (coccoid, coco-bacillary, ring, dumb-bell or horseshoe-shaped) bodies measuring approximately $0.3-1 \mu \mathrm{m}$ in diameter, either singly or in short chains on the erythrocytes or as free bodies in the plasma (Littlejohns, 1960; Hampel et al., 2014). However, it is challenging to differentiate $M$. ovis from stain deposit, cell fragments or other artefacts on Giemsa-stained preparations, presenting challenges to microscopic diagnosis (Gulland et al., 1987a; Neel, 2013). 
Nevertheless, acridine orange staining is significantly more effective than Giemsa for detection of low infections with less than $30 \%$ infected erythrocytes which may be the case in most field infections (Brun-Hansen et al., 1997). Moreover, light microscopy has limited sensitivity and specificity in the diagnosis of haemoplasma because of cyclic parasitemia and the prevalence of mild infections with low parasitaemia (Biondo et al., 2009). Therefore, the application of advanced microscopic techniques such as the fluorescent, confocal and scanning electron microscopes affords more excellent morphological details, yielding higher sensitivity and specificity in the diagnosis of M. ovis (Reagan et al., 1990; Neimark et al., 2001, 2004; Hoelzle et al., 2011). Even so, microscopy is far less specific than molecular detection methods which yield greater than 90\% diagnostic specificity (Hampel et al., 2014).

\section{Blood and serum analysis}

\section{Haematological examination}

The determination of blood count is widely used to support the clinical diagnosis of haemotropic mycoplasmosis in small ruminant practice (Hampel et al. 2014). The red blood cell (RBC), haemoglobin ( $\mathrm{Hb}$ ), white blood cell (WBC), erythrocyte indices (PCV, MCV, MCH and MCHC) and differential leucocytes (monocytes, lymphocytes, basophils, eosinophils and neutrophils) are routinely evaluated as an adjunct to the microscopic examination of the stained blood smear (Welle et al. 1995). The main characteristics of haemogram in acute haemoplasma infection of small ruminant are anaemia, neutrophilic left shift, monocytosis and lymphocytosis (Jesse et al. 2013). The primary biochemical changes accompanying M. ovis infection include hyponatremia, hypocalcemia, hypoalbuminemia, hypoproteinaemia and a concomitant increase in serum creatinine, indirect bilirubin, GGT, AST, ALP and BUN (Abed and Alsaad 2017).

\section{Acute phase protein assay}

The non-specific pathophysiological responses to diseases, inflammation or injury, which regulates tissue damage and repair process, are often referred to as the acute phase reactions (APRs) (Jain et al., 2011). Neoplasia, bacterial, parasitic and viral infections, burns, surgical procedures and immunological disturbances are common triggers for non-specific responses such as pyrexia, leucocytosis, hormonal alterations and muscle protein depletion which constitute the APR (Gruys et al., 2005). The APR cascade initiates the synthesis of Acute Phase glycoproteins (APP) by the hepatocytes of the liver in response to proinflammatory cytokines (IL-1, IL-6 and TNF- $\alpha$ ) released by the leucocytes (Horadagoda et al., 1999; Iliev \& Georgieva, 2018). Increased hepatic production of the positive APPs such as C-reactive protein (CRP), serum amyloid A (SAA) and haptoglobin (Hp) during the APR (Heinrich et al., 1990) decreases the concentration of negative plasma proteins like transthyretin (TTR), retinol-binding protein (RBP), cortisol binding globulin, transferrin and albumin (Gruys et al., 2005). Positive acute response prevents microbial growth and maintains homeostasis by opsonising complement, scavenging cellular remnants and free radicals, neutralising proteolytic enzymes and modulating the immune response of the host (Gruys et al., 2005; Jain et al., 2011).

Serum amyloid A (SAA) and haptoglobin (HP) are major APPs whose concentrations may be increased up to 10- and 100-fold, respectively, during APR in small ruminants (Jain et al., 2011; Iliev \& Georgieva, 2018). Haptoglobin (HP) is a positive plasma protein synthesised by the liver in response to growth hormone, insulin, bacterial endotoxin, prostaglandin, IL-1, IL-6 and tumour necrosis factor (Raynes, 2003). HP binds to free haemoglobin to form an HP-Hb complex which prevents the formation of oxygen radicals and the oxidative tissue damage accompanying haemolysis (Smith \& Roberts, 1994). Consequently, serum HP level decreases during haemolytic episodes and is therefore used as a reliable indicator of intravascular haemolysis (Jain et al., 2011). The HP-Hb complex also exerts bacteriostatic effects by making iron unavailable for bacterial cell metabolism (Ceciliani et al., 2012). Additionally, HP exerts anti-inflammatory and immunomodulatory roles by inhibiting Th2 response and mast cell proliferation (Murata et al., 2004). On the other hand, SAA participates in opsonisation, prevention of cholesterol aggregation at the site of inflammation and modulating the innate immune response during the APR (Jain et al., 2011; Iliev \& Georgieva, 2018).

Even though APPS are non-specific biomarkers, they represent appropriate analytes for the assessment of animal health and nutritional state (Gruys et al., 2005). The assay of APPs provides a medium for detecting tissue injury, inflammation and assessment of prognosis and progress of treatment in the clinical environment (Thompson et al., 1992). Serum amyloid A and haptoglobin are, therefore, useful clinical tools for discriminating between acute and chronic inflammatory processes (Horadagoda et al., 1999).

The APPs have so far been used as an aid to the diagnosis of bovine respiratory syncytial virus, bronchopneumonia, Streptococcus suis infection and neoplastic conditions (Jain et al., 2011). Elevated concentration of SAA is also associated with the diagnosis of clinical mastitis in dairy cows (Hirvonen et al., 1996; Hirvonen and Pyörälä, 1998). Both serum amyloid-A and haptoglobin are relevant nonspecific biomarkers used to support haemoplasma diagnosis (Murata et al., 2004; Korman et al., 2012). Diminished serum haptoglobin level coincided with a severe haemolytic episode during an outbreak of natural $M$. ovis infection in sheep flocks in Basra region of Iraq (Abed and Alsaad 2017), which provides a piece of evidence for the involvement of APPs in the 
pathogenesis of $M$. ovis infection in small ruminants. Since decreased levels of Hp supports the diagnosis of haemolytic anaemia (Jain et al., 2011), it is likely to analyse serum haptoglobin as a marker of $M$. ovis severity in small ruminants. However, despite considerable research efforts, many characteristics of APPs in small ruminant haemotropic mycoplasmosis have yet to be expounded.

\section{Serological detection of antibodies}

Concerted efforts were made in the development of serological tests to complement microscopy in the clinical diagnosis of haemotropic mycoplasmas in the late nineteenth century. Sheriff and Geering (1969) developed the popular Coomb's test (modified antiglobulin test), which relies on serum agglutination for detection of M. ovis antibodies in sheep blood. However, the antiglobulin test was short-lived due to poor specificity and high frequency of false-positive results. Kreier and Ristic (1963) developed an easy and specific indirect fluorescent antibody test (IFAT), which was superior to Coomb's antiglobulin test in the detection of ovine and bovine haemoplasmas. Ilemobade and Blotkamp (1978a) evaluated the specificity of IFAT for detection of Mycoplasma ovis in sheep while Nicholls and Veale (1986) later evaluated its reliability on experimentally infected sheep and recommended its application in serodiagnosis. Kabay et al. (1991) used IFAT on a large scale for the serological survey of E. ovis among weaner sheep in Australia. Daddow (1977) developed a complement fixation test (CFT) using antigens prepared from lysed red blood cells for serological detection of E. ovis in sheep, but the application of CFT was limited to the detection of only new infections. Lang et al. (1987) developed the enzyme-linked immunosorbent assay (ELISA) for the detection of serum antibody to $E$ ovis in sheep and is still in current use as a confirmatory test for diagnosis of $M$. ovis infection in small ruminants (Alleman et al. 1999; Abed and Alsaad 2017). Compared to CFT and IFAT, the ELISA is the preferred test for serodiagnosis and epidemiological survey of small ruminant flocks (Kanabathy and Nachiar 2004). Notwithstanding the merits of ELISA and other serological tests, their application is limited in the diagnosis because antibodies to M. ovis are transient (Hornok et al. 2009).

\section{Molecular detection of antigen}

Current diagnosis of $M$. ovis relies on the applications of more sensitive and specific methods based on nucleic acid amplification and sequencing. Advanced molecular approaches using polymerase chain reaction (PCR) and sequencing of the $16 \mathrm{~S}$ rRNA gene are now widely used to detect and characterise haemotropic mycoplasmas in animal and human infections (Sykes et al., 2010; Mohd Hassan et al., 2017; Wang et al., 2017). The evolution of PCR assays enhanced the efficiency of laboratory diagnosis and elucidated species diversity and host range of haemotropic mycoplasmas (Messick 2004). By using PCR, Neimark et al. (2004) analysed the 16S rRNA sequence of $E$. ovis and confirmed phylogenetic relationships with genus Mycoplasma (class Mollicutes), which led to the emergence of a new classification for the present-day haemotropic mycoplasmas. PCR and sequence analysis of the 16S rRNA gene of haemoplasma also helped to unravel novel species and host adaptations (Sykes et al., 2010). As a result, Messick et al. (2002) announced the discovery of new sequences corresponding to " $\mathrm{Ca}$. M. haemolamae" in Alpaca and " $\mathrm{Ca}$. M. haemodidelphidis" in the Opossum. Also came along the reports of $M$. ovis genome from captive cervids and free-ranging deer in Brazil (Grazziotin et al., 2011a, 2011b). Furthermore, Hornok et al. (2012), using PCR and sequencing during an investigation of haemolytic outbreak in Hungary, provided the first molecular evidence of Candidatus M. haemovis in goats. Similarly, Wang et al. (2017) reported the first occurrence of Candidatus M. haemovis among sheep and goats while Shi et al. (2018) provided the first evidence of " $\mathrm{Ca}$. M. haemobos" infection in goat and sheep in China. Furthermore, M. haemofelis, M. suis and M. ovis (Mascarelli et al., 2013) and $\mathrm{Ca}$. M. haemohominis (Steer et al., 2011) were also detected in humans while " $\mathrm{Ca}$. M. haemomacaque" was detected in Cynomolgus monkeys using PCR technology (Maggi et al., 2013).

PCR was also used in regular surveys and outbreaks to investigate the molecular epidemiology of haemotropic mycoplasmas in different parts of the world. Hornok et al. (2009) identified different strains of M. ovis in Northeast Hungary. M. wenyonii and "Ca. M. haemobos" were also detected by PCR in cattle and buffaloes in China, Germany and Malaysia (Su et al., 2010; Hoelzle et al., 2011; Mohd Hassan et al., 2017); M. haemocanis and " $\mathrm{Ca}$. M. haematoparvum" were detected in dogs (Soto et al., 2016; Kaewmongkol et al., 2017; Aktas and Ozubek 2018) while M. haemofelis, "Ca. M. haemominutum" and " $\mathrm{Ca}$. M. turicensis" were detected in cats (Vergara et al., 2016). Additionally, Song et al. (2014b) developed a more sensitive semi-nested PCR assay for the detection of M. ovis in China.

Before the development of quantitative real-time PCR assays, parasitaemia in haemoplasma infection was conservatively estimated using blood smear examination, which is subjective, cumbersome and requires a high level of expertise (Hampel et al., 2014). Real-time PCR assays are now available for evaluating the significance of a positive PCR result and monitoring the course of treatment. Real-time PCR has been used for the direct quantification of haemoplasma DNA (Tasker et al., 2003; Lobetti and Tasker 2004), and a universal assay with $98.2 \%$ sensitivity and $92.1 \%$ specificity was later developed for screening haemoplasma infections (Willi et al., 2009). So far, the qPCR assay has been used to study the transplacental and vector-borne transmission of bovine 
haemoplasmas (Hornok et al., 2011) and, in regular surveys, to determine the prevalence and risk factors of haemoplasmas among companion animals (Vergara et al., 2016; Soto et al., 2016). The introduction of qPCR in haemoplasma diagnosis, therefore, provides a more suitable alternative quantification technique.

Although the identification of nucleic acid by polymerase chain reaction (PCR) allows the rapid detection of unculturable haemoplasmas, most of the PCR assays in current diagnosis of $M$. ovis targets the universal 16S rRNA gene which provides limited information on emerging or existing species (Fenollar \& Raoult, 2004). Therefore, further studies are required to explore the genetic sequences of the 16S rRNA gene in order to identify the molecular basis for observed variations in the pathogenicity and virulence of field strains of haemotropic Mycoplasma ovis in small ruminants. The restriction fragment length polymorphism (RFLP) analysis of 16S rRNA amplicons was used in differentiating related haemoplasmas in small animals (Messick et al., 1998). However, this technique is yet to be implemented in studying the genotypes of $M$. ovis circulating among small ruminants. Additionally, comparative genomic analyses are widely employed to explain the genetic basis of virulence and predict potential virulence factors of many parasites. However, to date, there is no published information on the molecular basis of virulence in haemotropic M. ovis infection.

\section{Summary of findings and future perspectives}

Mycoplasma ovis is presently recognised as a haemotropic Mycoplasma (haemoplasma) in the Genus Mycoplasma (class Mollicutes). Haemotropic Mycoplasma ovis is an emerging pathogen affecting a wide range of mammalian hosts including sheep, goats, deer and man. Mechanical transmission is thought to occur through the bites of haematophagous arthropods and occasionally by contaminated sharp instruments. Healthy and well-nourished infected adult small ruminants usually resist infection and suppress parasitaemia to become persistent carriers, but younger naive animals become anaemic, unthrifty and stunted. Stressful conditions such as pregnancy, parturition, lactation, malnutrition, concurrent disease and handling increase susceptibility to acute infection. Haemolysis in acute disease is caused by direct damage to the erythrocyte membrane, increased RBC membrane fragility and erythrophagocytosis in the spleen and liver. Mycoplasma ovis infection has been reported in Africa, Asia, Australia, Europe, North and South America. In the Far East, only China, Japan, Malaysia and the Philippines have reported haemotropic Mycoplasma ovis in sheep, goats and deer. Microscopic examination of blood smear was the earliest method of antigen detection and characterisation of $M$. ovis parasitaemia in sheep and goats but various PCR assays (including real-time PCR) are now widely used for the direct detection, characterisation and quantification of haemoplasma infection. Notwithstanding the recent advancements in molecular diagnosis of haemoplasma infection, there is a dearth of information on the molecular epidemiology of haemotropic Mycoplasma ovis in East Asia, especially in Malaysia. Also, the efficiency of arthropod vectors in transmission and the effects of haemoplasma infection on productivity of small ruminants are essential aspects of epidemiology that warrants further investigation in Malaysia. Therefore, an extensive survey of small ruminant flocks and suspected arthropod vectors is necessary to elucidate the molecular epidemiology of M. ovis and chart a clear path towards the formulation of suitable interventions to mitigate its economic and public health consequences in Malaysia.

Acknowledgements Special thanks to colleagues and staff in the Clinical Research Laboratory, Faculty of Veterinary Medicine, Universiti Putra Malaysia, for their support in this project.

Authors' contributions FFAJ conceptualised the idea of this review; BPT conducted the literature search, analysis of data and preparation of drafts. All other authors have contributed equally in the critical revisions leading to the final draft of this manuscript.

\section{Compliance with ethical standards}

Conflict of interest The authors declare that they have no conflict of interest.

\section{References}

Abed, F. A. and Alsaad, K. M., 2017. Clinical, hematological and diagnostic studies of hemomycoplasma infection (Mycoplasma ovis) in sheep of Basrah Governorate. Basrah Journal of Veterinary Research, 16, 284-304.

Aguirre, D. H., Thompson, C., Neumann, R. D., Salatin, A. O., Gaido, A. B. and de Echaide, S. T., 2009. Clinical mycoplasmosis outbreak due to Mycoplasma ovis in sheep from Shalta, Argentina: Clinical, Microbiological and Molecular Diagnosis. Revista Argentina de Microbiología, 41, 212-214

Ait Lbacha, H., Alali, S., Zouagui, Z., El Mamoun, L., Rhalem, A., Petit, E., Haddad, N., Gandoin, C., Boulouis, H. J. and Maillard, R., 2015. High Prevalence of Anaplasma spp. in Small Ruminants in Morocco. Transboundary and Emerging Diseases, 64, 250-263. https://doi.org/10.1111/tbed.12366

Aktas, M. and Ozubek, S., 2017. A molecular survey of small ruminant hemotropic mycoplasmosis in Turkey, including first laboratory confirmed clinical cases caused by Mycoplasma ovis. Veterinary Microbiology, 208, 217-222. https://doi.org/10.1016/j.vetmic. 2017.08.011

Aktas, M. and Ozubek, S., 2018. A molecular survey of hemoplasmas in domestic dogs from Turkey. Veterinary Microbiology, 221, 94-97. https://doi.org/10.1016/j.vetmic.2018.06.004

Alleman, A. R., Pate, M. G., Harvey, J. W., Gaskin, J. M. and Barbet, A. F., 1999. Western immunoblot analysis of the antigens of Haemobartonella felis with sera from experimentally infected cats. Journal of Clinical Microbiology, 37, 1474-1479. 
Baker, H. J., Cassell, G. H. and Lindsey, J. R., 1971. Research complications due to Haemobartonella and Eperythrozoon infections in experimental animals. American Journal of Pathology, 64, 3, 625632.

Baneth, G., 2014. Tick-borne infections of animals and humans: A common ground. International Journal for Parasitology, 44, 9. https:// doi.org/10.1016/j.ijpara.2014.03.011

Biondo, A. W., Santos, A. P. D., Guimarães, A. M. S., Vieira, R. F. D. C., Vidotto, O., Macieira, D. D. B., Almosny, N. R. P., Molento, M. B., Timenetsky, J., Morais, H. A. D. and González, D., 2009. A review of the occurrence of hemoplasmas (hemotrophic mycoplasmas) in Brazil. Revista Brasileira de Parasitologia Veterinária, 18, 1-7. https://doi.org/10.4322/rbpv.0180300

Boes, K.M. and Durham, A.C., 2016. Bone Marrow, Blood Cells, and the Lymphoid/Lymphatic System, Sixth Edit (Elsevier Inc.)

Boes, K.M., Goncarovs, K.O., Thompson, C.A., Halik, L.A., Santos, A.P., Guimaraes, A.M., Feutz, M.M., Holman, P.J., Vemulapalli, R. and Messick, J.B., 2012. Identification of a Mycoplasma ovislike organism in a herd of farmed white-tailed deer (Odocoileus virginianus) in rural Indiana. Veterinary Clinical Pathology, 41, $77-83$

Brun-Hansen, H., Grønstøl, H., Waldeland, H. and Hoff, B., 1997. Eperythrozoon ovis infection in a commercial flock of sheep. Journal of Veterinary Medicine, Series B, 44, 295-299

Campbell, R. W., Sloan, C. A. and Harbutt, P. R., 1971. Observations on mortality in lambs in Victoria associated with Eperythrozoon ovis. Australian Veterinary Journal, 47, 538-541. https://doi.org/10.1111/ j.1751-0813.1971.tb02048.x

Cebra, C. and Cebra, M., 2012. Diseases of the hematologic, immunologic, and lymphatic systems (multisystem diseases). Sheep and goat medicine (WB Saunders). https://doi.org/10.1016/B978-14377-2353-3.10016-2

Ceciliani, F., Ceron, J. J., Eckersall, P. D. and Sauerwein, H., 2012. Acute phase proteins in ruminants. Journal of Proteomics, 75, 14, 42074231. https://doi.org/10.1016/j.jprot.2012.04.004

Chin, H. C., Ahmad, N. W., Kian, C. W., Kurahashi, H., Jeffery, J., Kiang, H. S. and Omar, B., 2010. A study of cow dung Diptera in Sentul Timur, Kuala Lumpur, Malaysia. Tropical Medicine and Parasitology, 33, 53-61

Chu, Z., Yin, J., Shen, K., Kang, W. and Chen, Q., 2009. Outbreaks of haemotrophic mycoplasma infections in China. Emerging Infectious Diseases, 15, 1139-1140. https://doi.org/10.3201/eid1507.08129

Cubilla, M. P., Santos, L. C., de Moraes, W., Cubas, Z. S., Leutenegger, C. M., Estrada, M., Vieira, R. F. C., Soares, M. J., Lindsay, L. L., Sykes, J. E. and Biondo, A. W., 2017. Occurrence of hemotropic mycoplasmas in non-human primates ( Alouatta caraya, Sapajus nigritus and Callithrix jacchus ) of southern Brazil. Comparative Immunology, Microbiology and Infectious Diseases, 52, 6-13. https://doi.org/10.1016/j.cimid.2017.05.002

Daddow, K. N., 1977. A Complement Fixation test for the detection of Eperythrozoon infection in Sheep. Australian Veterinary Journal, 53, 139-143. https://doi.org/10.1111/j.1751-0813.1977.tb00140.x

Daddow, K. N., 1980. Culex annulirostris as a vector of Eperythrozoon ovis infection in sheep. Veterinary Parasitology, 7, 313-317. https:// doi.org/10.1016/0304-4017(80)90051-5

Deshuillers, C. L., Santos, P. L., Do Nascimento, A. P., Hampel, N. C., Bergin, J. A., Dyson, I. L. and Messick, M. C. 2014. Complete genome sequence of Mycoplasma ovis strain Michigan, a hemoplasma of sheep with two distinct 16S rRNA genes. Genome Announcement, 2, 1235-1248. https://doi.org/10.1128/genomeA. 01235-13

dos Santos, A. P., dos Santos, R. P., Biondo, A. W., Dora, J. M., Goldani, L. Z., De Oliveira, S. T., de Sá Guimarães, A. M., Timenetsky, J., De Morais, H. A., González, F. H. and Messick, J. B., 2008. Hemoplasma infection in HIV-positive patient, Brazil. Emerging
Infectious Diseases, 14, 19-22 https://doi.org/10.3201/eid1412. 080964

Ershaduazzaman, M. D. and Iskandar, C. T. F. N., 2001. Characterization of Eperythrozoon ovis isolated from sheep and goats in Malaysia, (Unpublished $\mathrm{PhD}$ thesis, Universiti Putra Malaysia)

Erwanas, A. I., Masrin, A., Chandrawathani, P., Jamnah, O., Premaalatha, B. and Ramlan, M., 2015. Vectors of veterinary importance in Malaysia: a survey of biting flies in relation to trypanosomiasis in Perak. Malaysian Journal of Veterinary Research, 6, 8996

Fatimah, C. T. N. I., Siti-Zubaidah, R., Hair-Bejo, M., Siti-Nor, Y., Lee, C. C. and Davis, M. O., 1994. A case report of Eperythrozoonosis in a sheep. In Proceedings of the $2^{\text {nd }}$ Symposium on Sheep Production in Malaysia 22-24 November 1994, Serdang, Selangor.

Fatimah, C., Mariah, H. and Raha, A., 1998. The Epidemiology, pathogenesis and diagnosis of Eperythrozoonosis in Sheep (Unpublished Research Report, University Putra Malaysia)

Fenollar, F. and Raoult, D., 2004. Molecular genetic methods for the diagnosis of fastidious microorganisms. APMIS Journal of Pathology, Microbiology and Immunilogy, 112,11-12, 785-807. https://doi.org/10.1111/j.1600-0463.2004.apm11211-1206.x

Fitzpatrick, J. L., Barron, R. C. J., Andrew, L. and Thompson, H., 1998. Eperythrozoon ovis infection of sheep. Comparative Haematology International, 8, 230-234. https://doi.org/10.1007/BF02752854

Foley, J. E. and Pedersen, N. C., 2001. 'Candidatus Mycoplasma haemominutum', a low virulence epierythrocytic parasite of cats. International Journal of Systematic and Evolutionary Microbiology, 51, 815-817

Foogie, A. and Nisbet, D. I., 1964. Studies on Eperythrozoon infection in sheep. Journal Comparative Clinical Pathology, 74, 45-61. https:// doi.org/10.1016/S0368-1742(64)80006-0

Galon, E. M. S., Adjou Moumouni, P. F., Ybañez, R. H. D., Macalanda, A. M. C., Liu, M., Efstratiou, A., Ringo, A. E., Lee, S. H., Gao, Y., Guo, H., Li, J., Tumwebaze, M. A., Byamukama, B., Li, Y., Ybañez, A. P. and Xuan, X., 2019. Molecular evidence of hemotropic mycoplasmas in goats from Cebu, Philippines. The Journal of Veterinary Medical Science, 81, 6, 869-873. https://doi. org/10.1292/jvms.19-0042

Girotto-Soares, A., Soares, J.F., Bogado, A.L.G., de Macedo, C.A.B., Sandeski, L.M., Garcia, J.L. and Vidotto, O., 2016. 'Candidatus Mycoplasma haemobos': Transplacental transmission in dairy cows (Bos taurus). Veterinary Microbiology, 195, 22-24

Grazziotin, A. L., Duarte, J. M. B., Szabó, M. P. J., Santos, A. P., Guimarães, A. M. S., Mohamed, A., Vieira, R. F. D. C., de Barros Filho, I. R., Biondo, A. W. and Messick, J. B., 2011a. Prevalence and molecular characterization of Mycoplasma ovis in selected freeranging Brazilian deer populations. Journal of wildlife diseases, 47, 1005-1011.

Grazziotin, A. L., Santos, A. P., Guimaraes, A. M. S., Mohamed, A., Cubas, Z. S., De Oliveira, M. J., Dos Santos, L. C., De Moraes, W., da Costa Vieira, R. F., Donatti, L. and de Barros Filho, I. R., 2011b. Mycoplasma ovis in captive cervids: prevalence, molecular characterization and phylogeny. Veterinary microbiology, 152, 415419.

Gruys, E., Toussaint, M. J. M., Niewold, T. A. and Koopmans, S. J., 2005. Acute phase reaction and acute phase proteins. Journal of Zhejiang University: Science, 6, B11, 1045-1056. https://doi.org/ 10.1631/jzus.2005.B1045

Gulland, F. M., Doxey, D. L. and Scott, G. R., 1987a. Changing morphology of Eperythrozoon ovis. Research in Veterinary Science, 43, 88-91. https://doi.org/10.1016/s0034-5288(18)30748-3

Gulland, F. M., Doxey, D. L. and Scott, G. R., 1987b. The effects of Eperythrozoon ovis in sheep. Research in Veterinary Science, 43, 85-87. https://doi.org/10.1016/s0034-5288(18)30747-1

Hampel, J. A., Spath, S. N., Bergin, I. L., Lim, A., Bolin, S. R. and Dyson, M. C., 2014. Prevalence and diagnosis of hemotrophic 
mycoplasma infection in research sheep and its effects on hematology variables and erythrocyte membrane fragility. Comparative Medicine, 64, 478-485

Mohd Hassan, M. L. I., Kho, K. L., Koh, F. X., Hassan Nizam, Q. N. and Tay, S. T., 2017. Molecular evidence of hemoplasmas in Malaysian cattle and ticks. Tropical Biomedicine, 34, 668-674.

Heinrich, P. C., Castell, J. V. and Andus, T., 1990. Interleukin-6 and the acute phase response. Biochemical Journal, 265, 3, 621-636. https:// doi.org/10.1042/bj2650621

Hirvonen, J. and Pyörälä, S., 1998. Acute-phase response in dairy cows with surgically-treated abdominal disorders. Veterinary Journal, 155, 1, 53-61. https://doi.org/10.1016/S1090-0233(98)80036-1

Hirvonen, Juhani, Pyörälä, S. and Jousimies-Somer, H., 1996. Acute phase response in heifers with experimentally induced mastitis. Journal of Dairy Research, 63, 3, 351-360. https://doi.org/10. 1017/s0022029900031873

Hoelzle, K., Winkler, M., Kramer, M. M., Wittenbrink, M. M., Dieckmann, S. M. and Hoelzle, L. E., 2011. Detection of 'Candidatus Mycoplasma haemobos' in cattle with anaemia. Veterinary Journal, 187, 408-410. https://doi.org/10.1016/j.tvjl. 2010.01.016

Horadagoda, N. U., Knox, K. M., Gibbs, H. A., Reid, S. W., Horadagoda, A., Edwards, S. E. and Eckersall, P. D., 1999. Acute phase proteins in cattle: discrimination between acute and chronic inflammation. The Veterinary Record, 144, 16, 437-441. https://doi.org/10.1136/ vr.144.16.437

Hornok, Sándor, Hajtós, I., Meili, T., Farkas, I., Gönczi, E., Meli, M. and Hofmann-Lehmann, R., 2012. First molecular identification of Mycoplasma ovis and 'Candidatus M. haemoovis' from goat, with lack of haemoplasma PCR-positivity in lice. Acta Veterinaria Hungarica, 60, 355-360. https://doi.org/10.1556/avet.2012.030

Hornok, S, Micsutka, A., Meli, M. L., Lutz, H. and Hofmann-Lehmann, R., 2011. Molecular investigation of transplacental and vector-borne transmission of bovine haemoplasmas. Veterinary Microbiology, 152, 411-414. https://doi.org/10.1016/j.vetmic.2011.04.03

Hornok, Sándor, Lutz, H., Hofmann-Lehmann, R., Erdős, A., Meli, M. L. and Hajtós, I., 2009. Molecular characterization of two different strains of haemotropic mycoplasmas from a sheep flock with fatal haemolytic anaemia and concomitant Anaplasma ovis infection. Veterinary Microbiology, 136, 372-377. https://doi.org/10.1016/j. vetmic.2008.10.031

Huang, D. S., Guan, P., Wu, W., Shen, T. F., Liu, H. L., Cao, S. and Zhou, H., 2012. Infection rate of Eperythrozoon spp. in Chinese population: a systematic review and meta-analysis since the first Chinese case reported in 1991. BMC Infectious Diseases, 12, 1-8. https://doi.org/10.1186/1471-2334-12-17

Hung, A. L. and Lloyd, S., 1989. Role of the spleen and rosette-formation response in experimental Eperythrozoon ovis infection. Veterinary Parasitology, 32, 119-126. https://doi.org/10.1016/0304-4017(89) 90112-X

Hung, A. L. and Lloyd, S., 1985. Humoral response of sheep to infection with Eperythrozoon ovis. Research in Veterinary Science, 39, 275 278

Ilemobade, A. A. and Blotkamp, C., 1978a. Eperythrozoon ovis. I. Serological diagnosis of infection by the indirect immunofluorescent antibody test. Tropenmedizin und Parasitologie, 29, 307-310

Ilemobade, A. A. and Blotkamp, C., 1978b. Eperythrozoon ovis. II. Prevalence studies in sheep in Nigeria using the indirect immunofluorescent antibody test. Tropenmedizin und Parasitologie, 29, 311-314

Iliev, P. T. and Georgieva, T. M., 2018. Acute phase proteins in sheep and goats - function, reference ranges and assessment methods: An overview. Bulgarian Journal of Veterinary Medicine, 21, 1, 1-16. https://doi.org/10.15547/bjvm.1050

Jabbar, A., Abbas, T., Sandhu, Z. U. D., Saddiqi, H. A., Qamar, M. F. and Gasser, R. B., 2015. Tick-borne diseases of bovines in Pakistan:
Major scope for future research and improved control. Parasites and Vectors, 8, 1. https://doi.org/10.1186/s13071-015-0894-2

Jain, S., Gautam, V. and Naseem, S., 2011. Acute-phase proteins: As diagnostic tool. Journal of Pharmacy and Bioallied Sciences, 3, 118-127. https://doi.org/10.4103/0975-7406.76489

Jamnah, O., Faizal, H., Chandrawathani, P., Premaalatha, B., Erwanas, A., Rozita, L. and Ramlan, M., 2014. Eperythrozoonosis in Malaysian Pangolin. Malaysian Journal of Veterinary Research, 5, 65-69

Jesse, F. F. A., Abba, Y., Peter, I. D., Bitrus, A. A., Hambali, I. U., Jamaluddin, N. L. and Haron, A. W., 2017. Clinical management of parasitic gastroenteritis (PGE) concurrent with mycoplasmosis and orf in sheep. Advances in Animal and Veterinary Sciences, 5, 358-361

Jesse, F. F. A., Jazid, N. H. B. A., Mohamme, K., Tijjani, A., Chung, E. L. T., Abba, Y., Sadiq, M. A. and Saharee, A. A., 2015. Hemotropic Mycoplasma ovis infection in goats with concurrent gastrointestinal parasitism in Malaysia. Journal of Advanced Veterinary and Animal Research, 2, 464-468. https://doi.org/10.5455/javar.2015.b119

Jesse, F. F. A., Adamu, L., Osman, A. Y., Haron, A. W. and Saharee, A. A., 2013. Parasitic Gastro-enteritis (PGE) concurrent with Eperythrozoonosis in a goat: a case report. IOSR Journal of Agricultural and Veterinary Science, 4, 63-66

John, A. and Invermay, G., 1990. An Eperythrozoon ovis Outbreak in Merino lambs. Surveillance, 17, 15-16.

Johnson, K. A., do Nascimento, N. C., Bauer, A. E., Weng, H. Y., Kenitrahammac, G. and Messick, J. B., 2016. Detection of hemoplasma infection of goats by use of a quantitative polymerase chain reaction assay and risk factor analysis for infection. American Journal of Veterinary Research, 77, 882-889. https://doi.org/10. 2460/ajvr.77.8.882

Jongejan, F. and Uilenberg, G., 1994. Ticks and control methods. Revue Scientifique et Technique (International Office of Epizootics), 13, 1201-1226. https://doi.org/10.20506/rst.13.4.818

Kabay, M. J., Richards, R. B. and Ellis, T. E., 1991. A cross-sectional study to show Eperythrozoon ovis infection is prevalent in Western Australian sheep farms. Australian Veterinary Journal, 68, 170-173. https://doi.org/10.1111/j.1751-0813.1991.tb03172.x

Kaewmongkol, G., Lukkana, N., Yangtara, S., Kaewmongkol, S., Thengchaisri, N., Sirinarumitr, T., Jittapalapong, S. and Fenwick, S.G., 2017. Association of Ehrlichia canis, Hemotropic Mycoplasma spp. and Anaplasma platys and severe anemia in dogs in Thailand. Veterinary Microbiology, 201, 195-200 https://doi.org/ 10.1016/j.vetmic.2017.01.022

Kanabathy, S. G. and Nachiar, C. T. F., 2004. Immunological response of sheep to Eperythrozoon ovis infection, (Unpublished MSc thesis, Universiti Putra Malaysia)

Khadijah, S., Tan, F. H. A., Khadijah, S. S. A. K., Mursyidah Khairi, A. K., Nur Aida, H. and Wahab, A. R. (2014). Parasite Infection in two goat Farms Located in Kuala Terengganu, Peninsular Malaysia. Asian Journal of Agriculture and Food Sciences, 2, 463-468

Korman, R. M., Cerón, J. J., Knowles, T. G., Barker, E. N., Eckersall, P. D. and Tasker, S. 2012. Acute phase response to Mycoplasma haemofelis and 'Candidatus Mycoplasma haemominutum' infection in FIV-infected and non-FIV-infected cats. Veterinary Journal, 193, 433-438. https://doi.org/10.1016/j.tvj1.2011.12.009

Kreier, J. P. and Ristic, M., 1963. Morphologic, antigenic, and pathogenic characteristics of Eperythrozoon ovis and Eperythrozoon wenyoni. American Journal of Veterinary Research, 24, 488-500

Kshash, Q. H., 2017. Molecular detection of haemotropic Mycoplasma infection in sheep. Kufa Journal for Veterinary Medical Sciences, 8, $120-129$

Lang, F. M., Ferrier, G. R. and Nicholls, T. J., 1987. Detection of antibodies to Eperythrozoon ovis by the use of an enzyme-linked 
immunosorbent assay. Research in Veterinary Science, 43, 249252. https://doi.org/10.1016/S0034-5288(18)30782-3

Littlejohns, I. R., 1960. Eperythrozoonosis in sheep. Australian Veterinary Journal, 366, 260-265. https://doi.org/10.1111/j.17510813.1960.tb03777.x

Lobetti, R. G. and Tasker, S., 2004. Diagnosis of feline haemoplasma infection using a real-time PCR assay. Journal of the South African Veterinary Association, 75, 94-99

Machado, C. A., Vidotto, O., Conrado, F. O., Santos, N. J., Valente, J. D., Barbosa, I. C., Trindade, P. W., Garcia, J. L., Biondo, A. W., Vieira, T. S. and Vieira, R. F., 2017. Mycoplasma ovis infection in goat farms from northeastern Brazil. Comparative Immunology, Microbiology and Infectious Diseases, 55, 1-5

Maggi, R. G., Mascarelli, P. E., Balakrishnan, N., Rohde, C. M., Kelly, C. M., Ramaiah, L., Leach, M. W. and Breitschwerdt, E. B., 2013. "Candidatus Mycoplasma haemomacaque" and Bartonella quintana bacteremia in cynomolgus monkeys. Journal of Clinical Microbiology, 51, 1408-1411. https://doi.org/10.1128/JCM.0301912

Martínez-Hernández, J. M., Ballados-González, G. G., FernándezBandala, D., Martínez-Soto, S., Velázquez-Osorio, V., MartínezRodríguez, P. B., Cruz-Romero, A., Grostieta, E., LozanoSardaneta, Y., Salas, P. C. and Becker, I., 2019. Molecular detection of Mycoplasma ovis in an outbreak of hemolytic anemia in sheep from Veracruz, Mexico. Tropical Animal Health and Production, 51, 243-248. https://doi.org/10.1007/s11250-018-1648-x

Mascarelli, P. E., Keel, M. K., Yabsley, M., Last, L. A., Breitschwerdt, E. B. and Maggi, R. G., 2014. Hemotropic mycoplasmas in little brown bats (Myotis lucifugus). Parasites and Vectors, 7, 117

Mascarelli, P. E., Maggi, R. G., Compton, S. M., Trull, C. L., Breitschwerdt, E. B., and Mozayeni, B. R., 2013. Infection with Hemotropic Mycoplasma Species in Patients with or without Extensive Arthropod or Animal Contact. Journal of Clinical Microbiology, 51, 3237-3241. https://doi.org/10.1128/jcm.0112513

Mason, R. W. and Statham, P., 1991. The determination of the level of Eperythrozoon ovis parasitaemia in chronically infected sheep and its significance to the spread of infection. Australian Veterinary Journal, 68, 115-116. https://doi.org/10.1111/j.1751-0813.1991. tb00771.x

Mason, R. W., Corbould, A., and Statham, P., 1989. A serological survey of Eperythrozoon ovis in goats and sheep in Tasmania. Australian Veterinary Journal, 66, 122-123. https://doi.org/10.1111/j.17510813.1989.tb09767.x

Meichner, K., Qurollo, B. A., Anderson, K. L., Grindem, C. B., Savage, M. and Breitschwerdt, E. B., 2015. Naturally Occurring Ehrlichia ewingii and Mycoplasma sp. Co-Infection in a Goat. Journal of Veterinary Internal Medicine, 29, 6, 1735-1738. https://doi.org/10. 1111 jvim. 13644

Messick, J. B., 2004. Hemotrophic mycoplasmas (hemoplasmas): A review and new insights into pathogenic potential. Veterinary Clinical Pathology, 2-13. https://doi.org/10.1111/j.1939-165X.2004. tb00342.x

Messick, J. B., Walker, P. G., Raphael, W., Berent, L. and Shi, X., 2002. 'Candidatus Mycoplasma haemodidelphidis' sp. nov., 'Candidatus Mycoplasma haemolamae' sp. nov. and Mycoplasma haemocanis comb. nov., haemotrophic parasites from a naturally infected opossum (Didelphis virginiana), alpaca (Lama pacos) and dog (Canis famili). International Journal of Systematic and Evolutionary Microbiology, 52, 693-698. https://doi.org/10.1099/ijs.0.01861-0

Messick, J. B., Cooper, S. K. and Huntley, M., 1999. Development and Evaluation of a Polymerase Chain Reaction Assay Using the 16S rRNA Gene for Detection of Eperythrozoon suis Infection. Journal of Veterinary Diagnostic Investigation, 11, 229-236. https://doi.org/ $10.1177 / 104063879901100304$
Messick, J. B., Berent, L. M. and Cooper, S. K., 1998. Development and evaluation of a PCR-based assay for detection of Haemobartonella felis in cats and differentiation of $\mathrm{H}$. felis from Related bacteria by restriction fragment length polymorphism analysis. Journal of Clinical Microbiology, 36, 2, 462-466. https://doi.org/10.1128/ jcm.36.2.462-466.1998

Millán, J., López-Roig, M., Delicado, V., Serra-Cobo, J. and Esperón, F., 2015. Widespread infection with hemotropic mycoplasmas in bats in Spain, including a hemoplasma closely related to 'Candidatus Mycoplasma hemohominis'. Comparative Immunology, Microbiology and Infectious Diseases, 39, 9-12. https://doi.org/10. 1016/j.cimid.2015.01.002

Murata, H., Shimada, N. and Yoshioka, M., 2004. Current research on acute phase proteins in veterinary diagnosis: An overview. The Veterinary Journal, 168, 28-40. https://doi.org/10.1016/S10900233(03)00119-9

Neel, J. A., 2013. Blood Smear Basics. NC State college of Veterinary Medicine (Raleigh, North Carolina)

Neimark, H., Hoff, B. and Ganter, M. (2004). Mycoplasma ovis comb. nov. (formerly Eperythrozoon ovis), an epierythrocytic agent of haemolytic anaemia in sheep and goats. International Journal of Systematic and Evolutionary Microbiology, 54, 365-371. https:// doi.org/10.1099/ijs.0.02858-0

Neimark, H., Johansson, K.-E., Rikihisa, Y. and Tully, J. G., 2002. Revision of haemotrophic Mycoplasma species names. International Journal of Systematic and Evolutionary Microbiology, 52, 683. https://doi.org/10.1099/ijs.0.02283-0

Neimark, H., Johansson, K. E., Rikihisa, Y. and Tully, J. G., 2001. Proposal to transfer some members of the genera Haemobartonella and Eperythrozoon to the genus Mycoplasma with descriptions of 'Candidatus Mycoplasma haemofelis', 'Candidatus Mycoplasma haemomuris', 'Candidatus Mycoplasma haemosuis' and 'Candidatus Mycoplasma wenyonii' International Journal of Systematic and Evolutionary Microbiology, 51, 891-899. https:// doi.org/10.1099/00207713-51-3-891

Neimark, H. and Kocan, K. M., 1997. The cell wall-less rickettsia Eperythrozoon wenyonii is a Mycoplasma. Microbiology Letters, 156, 287-291. https://doi.org/10.1111/j.1574-6968.1997.tb12742.x

Neitz, W., Alexander, R. and Du Toit, P., 1934. Eperythrozoon ovis (sp. nov.) infection in sheep. Onderstepoort Journal of Veterinary Research, 11, 263-271

Nicholls, T. J. and Veale, P. I., 1986. A modified indirect immunofluorescent assay for the detection of antibody to Eperythrozoon ovis in sheep. Australian Veterinary Journal, 63, 157-159. https://doi.org/ 10.1111/j.1751-0813.1986.tb02956.x

Norris, M. J., Rahaley, R. S. and Whittaker, R. G., 1987. Effect of Eperythrozoon ovis on the lysis of sheep erythrocytes in the complement fixation test. Veterinary Immunology and Immunopathology, 16, 283-288. https://doi.org/10.1016/01652427(87)90025-0

Ohder, H., 1967. Some observations on Eperythrozoon infection in nonsplenectomized sheep and the detection of the parasites and their antibodies by immunofluorescence. Zentralblatt fur Bakteriologie, Parasitenkunde, Infektionskrankheiten und Hygiene, 203, 391-401

Ohtake, Y., Nishizawa, I., Sato, M., Watanabe, Y., Nishimura, T., Matsubara, K., Nagai, K. and Harasawa, R., 2011. Mycoplasma ovis detected in free-living Japanese serows, Capricornis crispus. Journal of Veterinary Medical Science, 73, 3, 371-373. https://doi. org/10.1292/jvms.10-0383

Philbey, A. W., Barron, R. C. J. and Gounden, A., 2006. Chronic eperythrozoonosis in an adult ewe. Veterinary Record, 158, 662664. https://doi.org/10.1136/vr.158.19.662

Porter, R. and Kaplan, J., 2011. The Merck manual of diagnosis and therapy (Merck Sharp and Dohme Corp, New Jersey)

Rani, N., Tomar, P., Kapoor, P. K. and Singh, Y., 2018. A Review on Emerging Zoonotic Mycoplasma. International Journal of Pure and 
Applied Bioscience, 6, 784-790. https://doi.org/10.18782/23207051.7028

Raynes, J. G., 2003. The acute phase response. NeuroImmune Biology, 3C, 463-494. https://doi.org/10.1016/S1567-7443(03)80059-5

Reagan, W. J., Carry, F., Thrall, M. A., Colgan, S., Hutchison, J. and Weiser, M. G., 1990. The Clinicopathologic, light, and scanning electron microscopic features of eperythrozoonosis in four naturally infected Llamas. Veterinary Pathology, 27, 426-431

Rikihisa, Y., Kawahara, M., Wen, B., Kociba, G., Fuerst, P., Kawamori, F., Suto, C., Shibata, S. and Futohashi, M., 1997. Western immunoblot analysis of Haemobartonella muris and comparison of $16 \mathrm{~S}$ rRNA gene sequences of $H$. muris, $H$. felis, and Eperythrozoon suis. Journal of Clinical Microbiology, 35, 823-829

Rjeibi, M. R., Darghouth, M. A., Houda, O., Khemaïs, S., Mourad, R. and Mohamed, G., 2015. First molecular isolation of Mycoplasma ovis from small ruminants in North Africa. Onderstepoort Journal of Veterinary Research, 82, 1-5. https://doi.org/10.4102/ojvr.v82i1. 912

Robson, S. and Kemp, B., 2007. Eperythrozoonosis in sheep. Prime facts, 466. https://doi.org/10.1007/978-90-481-8725-6

Saleeza, S. N. R., Norma-Rashid, Y. and Azirun, M. S., 2013. Mosquito species and outdoor breeding places in residential areas in Malaysia. Southeast Asian Journal of Tropical Medicine and Public Health, 44, 963-969

Scott, R., 2008. Distal hind limb and udder oedema of dairy cattle associated with an unidentified haemotrophic bacterium with microscopic characteristics of Mycoplasma (formerly Eperythrozoon) wenyonii. Cattle Practice, 16, 50-53

Seamer, J., 1959. The propagation and preservation of Eperythrozoon coccoides. Journal of General Microbiology, 21, 344-351. https:// doi.org/10.1099/00221287-21-2-344

Seo, M. G., Kwon, O. D. and Kwak, D., 2019. Prevalence and phylogenetic analysis of hemoplasma species in domestic pigs in Korea. Parasites and Vectors, 12, 1. https://doi.org/10.1186/s13071-0193638-x

Sheriff, D. and Geering, M. C., 1969. The antiglobulin (Coombs) test in Eperythrozoon ovis infection in sheep. Australian Veterinary Journal, 45, 505-507. https://doi.org/10.1111/j.1751-0813.1969. tb07877.x

Shi, H., Hu, Y., Leng, C., Shi, H., Jiao, Z., Chen, X., Peng, Y., Yang, H., Kan, Y. and Yao, L., 2018. Molecular investigation of "Candidatus Mycoplasma haemobos" in goats and sheep in central China. Transboundary and emerging diseases, 66, 22-27. https://doi.org/ 10.1111/tbed.13021

Smith, D. J. and Roberts, D., 1994. Effects of high volume and/or intense exercise on selected blood chemistry parameters. Clinical Biochemistry, 27, 6, 435-440. https://doi.org/10.1016/00099120(94)00055-Z

Smith, J. A. L., Thrall, M. A., Smith, J. A. L., Salman, M. D., Ching, S. V. and Collins, J. K., 1990. Eperythrozoon wenyonii infection in dairy cattle. Journal of the American Veterinary Medical Association, $196,1244-1250$

Song, Q., Zhang, W., Song, W., Liu, Z., Khan, M.K., He, L., Fang, R., Li, P., Zhou, Y., Hu, M. and Zhao, J., 2014a. Seroprevalence and risk factors of Mycoplasma suis infection in pig farms in central China. Preventive veterinary medicine, 117, 215-221. https://oi.org/10. 1016/j.prevetmed.2014.07.006

Song, W., Song, Q., He, L., Zhou, Y. and Zhao, J., 2014b. The establishment and application of a semi-nested PCR assay for the detection of Mycoplasma ovis. Small Ruminant Research, 119, 176-181. https:// doi.org/10.1016/j.smallrumres.2014.03.001

Song, H. Q., Zhu, X. Q., Yuan, Z. G., Lin, R. Q., Zhao, G. H., Su, Q. L., Yang, J. F. and Huang, W. Y., 2010. The detection of "Candidatus Mycoplasma haemobos" in cattle and buffalo in China. Tropical Animal Health and Production, 42, 8, 1805-1808. https://doi.org/ 10.1007/s11250-010-9640-0
Soto, F., Walker, R., Sepulveda, M., Bittencourt, P., Acosta-Jamett, G. and Müller, A., 2016. Occurrence of canine hemotropic mycoplasmas in domestic dogs from urban and rural areas of the Valdivia Province, southern Chile. Comparative Immunology, Microbiology and Infectious Diseases, 50, 70-77. https://doi.org/10.1016/j.cimid. 2016.11.013

Souza, U. A., Oberrather, K., Fagundes-Moreira, R., Almeida, B. A. de, Valle, S. de F., Girotto-Soares, A., and Soares, J. F. 2019. First molecular detection of Mycoplasma ovis (Hemotropic mycoplasmas) from Sheep in Brazil. Revista Brasileira de Parasitologia Veterinária, 28, 3, 360-366. https://doi.org/10.1590/s198429612019022

Steer, J. A., Tasker, S., Barker, E. N., Jensen, J., Mitchell, J., Stocki, T., Chalker, V. J. and Hamon, M., 2011. A novel hemotropic Mycoplasma (hemoplasma) in a patient with hemolytic anemia and pyrexia. Clinical Infectious Diseases, 53, 147-151

Stoffregen, W. C., Alt, D. P., Palmer, M. V., Olsen, S. C., Waters, W. R. and Stasko, J. A., 2006. Identification of a Haemomycoplasma species in anemic Reindeer (Rangifer tarandus). Journal of Wildlife Diseases, 42, 249-258. https://doi.org/10.7589/0090-3558-42.2.249

Stoffregen, W.C., Alt, D.P., Palmer, M. V., Olsen, S.C., Waters, W.R. and Stasko, J.A., 2013. Identification of a Haemomycoplasma Species in Anemic Reindeer (Rangifer tarandus). Journal of Wildlife Diseases, 42, 249-258

Su, Q.L., Song, H.Q., Lin, R.Q., Yuan, Z.G., Yang, J.F., Zhao, G.H., Huang, W.Y. and Zhu, X.Q., 2010. The detection of "Candidatus Mycoplasma haemobos" in cattle and buffalo in China. Tropical Animal Health and Production, 42, 805-1808. https://doi.org/10. 1007/s11250-010-9640-0

Suh, G. H., Ahn, K. S., Ahn, J. H., Kim, H. J., Leutenegger, C. and Shin, S. S., 2017. Serological and molecular prevalence of canine vectorborne diseases (CVBDs) in Korea. Parasites and Vectors, 10, 1. https://doi.org/10.1186/s13071-017-2076-x

Sutton, R. H. and Jolly, R. D., 1973. Experimental Eperythrozoon ovis infection of sheep. New Zealand Veterinary Journal, 21, 160-166. https://doi.org/10.1080/00480169.1973.34097

Suzuki, J., Sasaoka, F., Fujihara, M., Watanabe, Y., Tasaki, T., Oda, S., Kobayashi, S., Sato, R., Nagai, K. and Harasawa, R., 2011. Molecular identification of 'Candidatus Mycoplasma haemovis' in sheep with hemolytic anemia. Journal of Veterinary Medical Science, 73, 1113-1115. https://doi.org/10.1292/jvms.11-0113

Sykes, J. E., Lindsay, L. A. L., Maggi, R. G. and Breitschwerdt, E. B., 2010. Human coinfection with Bartonella henselae and two hemotropic mycoplasma variants resembling Mycoplasma ovis. Journal of Clinical Microbiology, 48, 3782-3785. https://doi.org/ 10.1128/JCM.01029-10

Tagawa, M., Matsumoto, K., Yokoyama, N. and Inokuma, H., 2014. Prevalence and molecular analyses of hemotrophic mycoplasma spp. (hemoplasmas) detected in sika deer (Cervus nippon yesoensis) in Japan. Journal of Veterinary Medical Science, 76, 3, 401-407. https://doi.org/10.1292/jvms.13-0486

Tagawa, M., Takeuchi, T., Fujisawa, T., Konno, Y., Yamamoto, S., Matsumoto, K., Yokoyama, N. and Inokuma, H., 2012a. A Clinical Case of Severe Anemia in a Sheep Coinfected with Mycoplasma ovis and 'Candidatus Mycoplasma haemovis' in Hokkaido, Japan. Journal of Veterinary Medical Science, 74, 99102. https://doi.org/10.1292/jvms.11-0296

Tagawa, M., Ybanez, A. P., Matsumoto, K., Yokoyama, N. and Inokuma, H., 2012b. Prevalence and risk factor analysis of bovine hemoplasma infection by direct PCR in Eastern Hokkaido, Japan. Journal of Veterinary Medical Science, 74, 9, 1171-1176. https:// doi.org/10.1292/jvms.12-0118

Tasker, S., Helps, C. R., Day, M. J., Gruffydd-Jones, T. J. and Harbour, D. A., 2003. Use of real-time PCR to detect and quantify Mycoplasma haemofelis and 'Candidatus Mycoplasma 
haemominutum' DNA. Journal of Clinical Microbiology, 41, 439441. https://doi.org/10.1128/JCM.41.1.439-441.2003

Theiss, P., Karpas, A. and Wise, K.S., 1996. Antigenic topology of the P29 surface lipoprotein of Mycoplasma fermentans: differential display of epitopes results in high-frequency phase variation. Infection and immunity, 64(5), 1800-1809

Thompson, D., Milford-Ward, A. and Whicher, J. T., 1992. The value of acute phase protein measurements in clinical practice. Annals of Clinical Biochemistry, 29, 2, 123-131. https://doi.org/10.1177/ 000456329202900201

Urie, N.J., Highland, M.A., Knowles, D.P., Branan, M.A., Herndon, D.R. and Marshall, K.L., 2019. Mycoplasma ovis infection in domestic sheep (Ovis aries) in the United States: Prevalence, distribution, associated risk factors, and associated outcomes. Preventive Veterinary Medicine, 171, 104750

Varanat, M., Maggi, R. G., Linder, K. E. and Breitschwerdt, E. B., 2011. Molecular Prevalence of Bartonella, Babesia, and Hemotropic Mycoplasma sp. in Dogs with Splenic Disease. Journal of Veterinary Internal Medicine, 25, 6, 1284-1291. https://doi.org/10. 1111/j.1939-1676.2011.00811.x

Vergara, W. R., Galleguillos, F. M., Jaramillo, M. G., Almosny, N. R. P., Martínez, P. A., Behne, P. G., Acosta-Jamett, G. and Müller, A., 2016. Prevalence, risk factor analysis, and hematological findings of hemoplasma infection in domestic cats from Valdivia, Southern Chile. Comparative Immunology, Microbiology and Infectious Diseases, 46, 20-26

Volokhov, D. V, Hwang, J., Chizhikov, V. E., Danaceau, H., and Gottdenker, N. L., 2017. Prevalence, Genotype Richness, and Coinfection Patterns of Hemotropic Mycoplasmas in Raccoons (Procyon lotor) on Environmentally Protected and Urbanized Barrier Islands. Applied and Environmental Microbiology, 83, e00211-17. https://doi.org/10.1128/aem.00211-17

Wang, X., Cui, Y., Zhang, Y., Shi, K., Yan, Y., Jian, F., Zhang, L., Wang, R. and Ning, C., 2017. Molecular characterization of hemotropic mycoplasmas (Mycoplasma ovis and 'Candidatus Mycoplasma haemovis') in sheep and goats in China. BMC Veterinary Research, 13, 142. https://doi.org/10.1186/s12917-017-1062-z

Watanabe, Y., Fujihara, M., Obara, H., Matsubara, K., Yamauchi, K. and Harasawa, R., 2010. Novel hemoplasma species detected in freeranging sika deer (Cervus nippon). Journal of Veterinary Medical Science, 72, 11, 1527-1530). https://doi.org/10.1292/jvms.10-0229

Welle, E. G., Tyler, J. W. and Wolfe, D. F., 1995. Hematologic and semen quality changes in bulls with experimental Eperythrozoon infection. Theriogenology, 43, 427-437

Westmoreland, L. S. H., Stoskopf, M. K. and Maggi, R. G., 2017. Detection and prevalence of four different hemotropic Mycoplasma spp. in Eastern North Carolina American black bears (Ursus americanus). Comparative Immunology, Microbiology and
Infectious Diseases, 50, 106-109. https://doi.org/10.1016/j.cimid. 2016.12.002

Willi, B., Meli, M.L., Lüthy, R., Honegger, H., Wengi, N., Hoelzle, L.E., Reusch, C.E., Lutz, H. and Hofmann-Lehmann, R., 2009. Development and application of a universal hemoplasma screening assay based on the SYBR Green PCR principle. Journal of Clinical Microbiology, 47, 4049-4054. https://doi.org/10.1128/JCM.0147809

Yang, D., Xiuzheng, T. A. I., Ying, Q. I. U. and Sheng, Y. U. N., 2000. Prevalence of Eperythrozoon spp. infection and congenital eperythrozoonosis in humans in inner Mongolia, China. Epidemiology and Infection, 125, 421-426. https://doi.org/10. 1017/S0950268899004392

Ybañez, Adrian P., Ybañez, R. H. D., Armonia, R. K. M., Chico, J. K. E., Ferraren, K. J. V., Tapdasan, E. P., Salces, C. B., Maurillo, B. C. A., Galon, E. M. S., Macalanda, A. M. C., Moumouni, P. F. A. and Xuan, X., 2019. First molecular detection of Mycoplasma wenyonii and the ectoparasite biodiversity in dairy water buffalo and cattle in Bohol, Philippines. Parasitology International, 70, 77-81. https:// doi.org/10.1016/j.parint.2019.02.004

Ybañez, Adrian Patalinghug, Ybañez, R. H. D. and Tagawa, M., 2015. Molecular Detection of Hemoplasma Species (Mycoplasma spp.) in Cattle in Cebu, Philippines Adrian. Journal of Advanced Veterinary Research, 5, 1, 43-46.

Yuan, C. L., Liang, A. B., Yao, C. B., Yang, Z. B., Zhu, J. G., Cui, L., Yu, F., Zhu, N. Y., Yang, X. W. and Hua, X. G., 2009. Prevalence of Mycoplasma suis (Eperythrozoon suis) infection in swine and swine-farm workers in Shanghai, China. American Journal of Veterinary Research, 70, 890-894. https://doi.org/10.2460/ajvr.70. 7.890

Yuan, C. L., Liang, A. B., Yu, F., Yang, Z., Li, Z., Zhu, J., Cui, L., Han, Y. and Hua, X., 2007a. Eperythrozoon infection identified in an unknown aetiology anaemia patient. Annals of Microbiology, 57, 467-469. https://doi.org/10.1007/BF03175091

Yuan, C. L., Yang, Z., Zhu, J., Cui, L. and Hua, X., 2007b. Effect of an immunosuppressor (dexamethasone) on Eperythrozoon infection. Veterinary Research Communications, 31, 661-664. https://doi. org/10.1007/s11259-007-0029-0

Zuo-yong, Z., Kui, N., Shi-jun, H., Hong-lin, L., Ming, T., You-lan, H., Cheng, T., Jian, Y. and Jin, X., 2010. Infection rate and risk factors analysis of Haemotrophic Mycoplasma (formerly Eperythrozoon ovis) in Chongqing area. Chinese Journal of Preventive Veterinary Medicine, 32, 563-6.

Publisher's note Springer Nature remains neutral with regard to jurisdictional claims in published maps and institutional affiliations. 